\title{
Host-plant resistance to insects in sorghum and its role in integrated pest management
}

\author{
H C Sharma \\ International Crops Research Institute for the Semi Alid Tropic (ICRISAT) Patancheru Andhra \\ Pradesh 502324 India
}

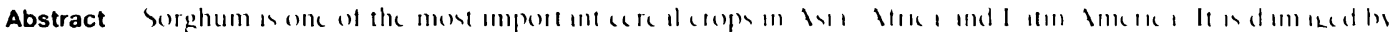

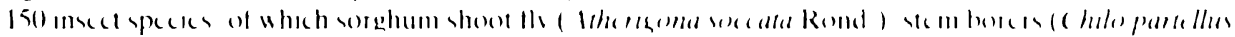

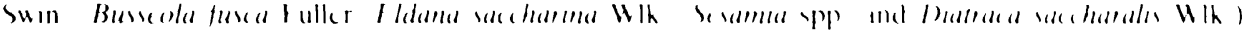

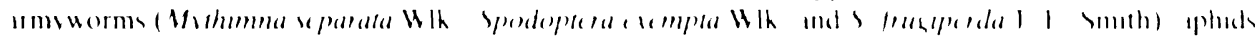

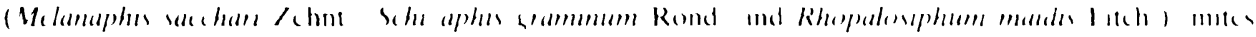

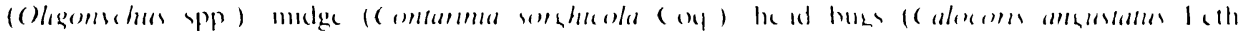

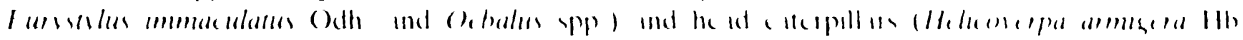

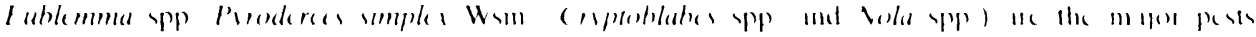

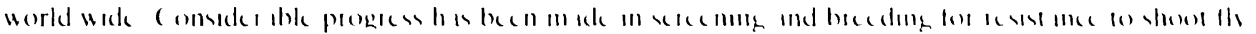

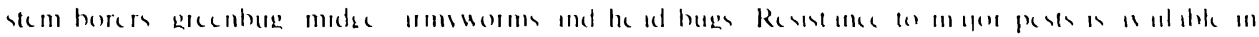

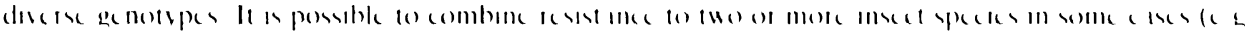

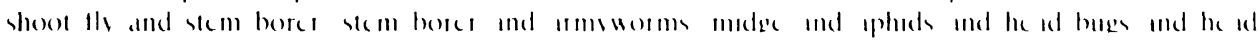

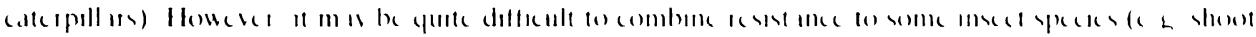

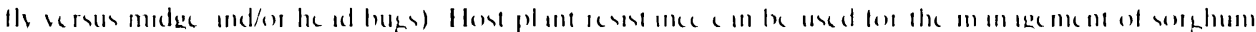

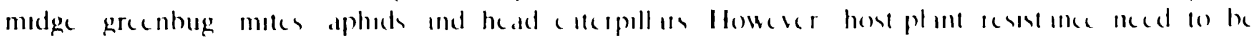

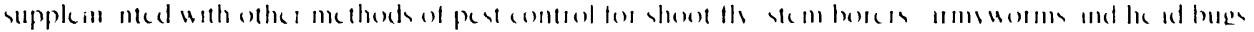

Keywords Sorghum Sorghum bic olor pest mandagement host plant re st turce

\section{Introduction}

Sorghum Sorghum buelen (I ) Mounch one of the most important cercals in the seme-ardatepes presides

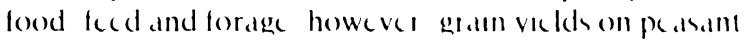
farms ale gencrally low owing partle to meel pest damage (Doggett 1988) Nearle 150 ypeces of msects have been recorded as pests of sorghum (Redds and Davics 1979 lotwan Young and lectes l98(1) the damage economic importance and destribution of most important pests are listed in Table I Avordable vicld losses have been cstamated at me.arls 22"0 in Indlat (Bolad and Mittal l9d3) 9", If USA (Wheman and Morrison |9x|) and nearly 20", in Atrka ( 10 tral Amerkat and Mexke) Ithe finamelal lose is mearle A 850$)$ $\times 10^{\prime}$ due 10 madge alome in Austadid (IC RISA I $1985)$ and $R, 100 \times 10^{\circ}$ dec 10 pancke-keding insects in Indla (I cuschner and Shatma 1983)

Recommendations for integrated pest management (IPM) in sorghum involve cultural practices natural enemies host plant resistance and insccticides In ranted agsculture the sowing date cannot be mampulated to avold pest damage so sowng pest resistant cultivars is especlally useful under subsistence farming conditions of the semi-drid tropes (Davies 1981) Unfortunatel newly developed cultivars often fal the challenge of heterogencous pest populations

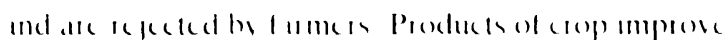

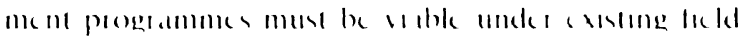

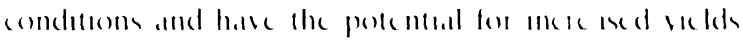

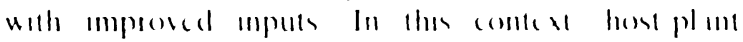

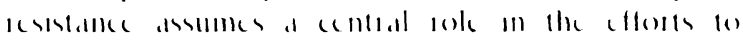

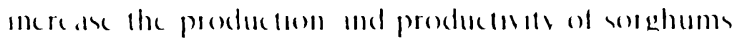

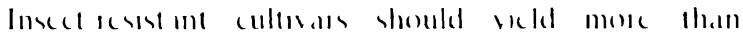
susceptible cultur us in the presence of pests and weld at kas a mexh as the susceptoble culla ins in the

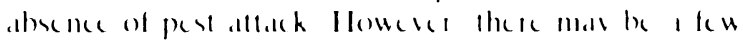
creptems when the pest problems are oncentelmeng (I) oggent starks and I buhalt 1970) low veldang

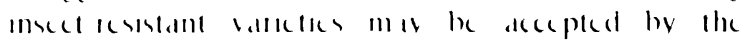
farmers Pest mallagement in sorghum has bech

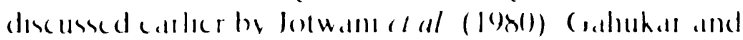

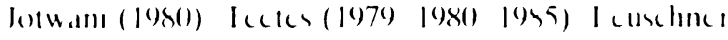
I anc ja and Sharma (1985) and bhama (1955) In thas

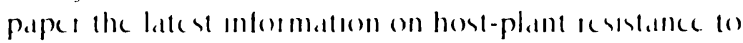

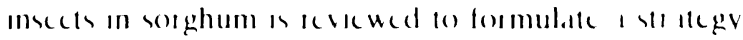
for the use of kesstant culations in integratced pest management in diftecolit agroceosvicms

\section{Host-plant resistance to insects}

Shoot fly (Atherigona soccata Rond)

studics in the All Indla (oordmatled sorghum Impeorcment Project (AIC SIP) it IC RISAI and in 
Table 1 Important arthropod pests of sorghum ${ }^{d}$

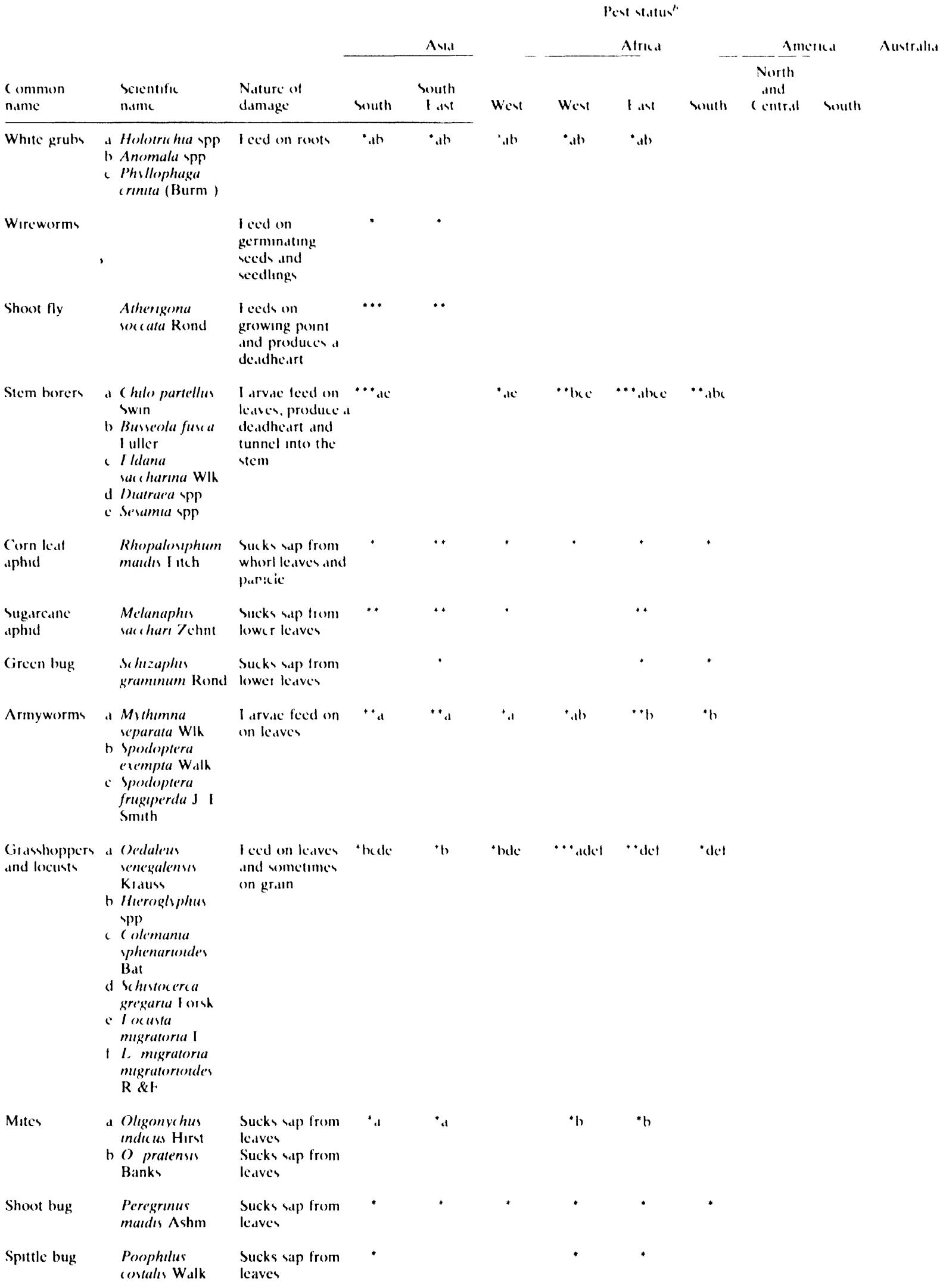




\begin{tabular}{|c|c|c|c|c|c|c|c|c|c|c|c|c|}
\hline \multirow[b]{3}{*}{$\begin{array}{l}\text { (ommon } \\
\text { namic }\end{array}$} & \multirow{3}{*}{\multicolumn{2}{|c|}{$\begin{array}{l}\text { Sucntific } \\
\text { name }\end{array}$}} & \multirow[b]{3}{*}{$\begin{array}{l}\text { Nature of } \\
\text { d.amalge }\end{array}$} & \multicolumn{9}{|c|}{ Pust st ifus' } \\
\hline & & & & & Asta & & & Altis. & & $\Delta \mathrm{m}$ & ricad & lustralial \\
\hline & & & & south & $\begin{array}{l}\text { buuth } \\
1 \text { ast }\end{array}$ & ucs & u(u) & 1 小 & south & $\begin{array}{c}\text { North } \\
\text { und } \\
\text { ( ontr.ll }\end{array}$ & south & \\
\hline $\begin{array}{l}\text { Sorghum } \\
\text { midge }\end{array}$ & & $\begin{array}{l}\text { Comlarima } \\
\text { sorghiucola }(\text { oy }\end{array}$ & $\begin{array}{l}\text { I arvale teed on } \\
\text { developing grann }\end{array}$ & $\cdots$ & • & $\because$ & $\cdots$ & $\cdots$ & $*$ & $\cdots$ & $* *$ & $\cdots$ \\
\hline Head bugs & $\begin{array}{l}\text { a } \\
b \\
\text { d } \\
\text { d }\end{array}$ & 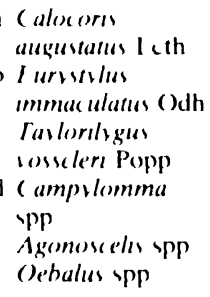 & $\begin{array}{l}\text { Suchs sap from } \\
\text { developing grann }\end{array}$ & $\cdots$ ide & & cde & $\cdots$ bude & "uk & •ud & $\cdots 1$ & of & \\
\hline Bectles & $\begin{array}{l}\text { d } \\
b \\
d \\
d\end{array}$ & $\begin{array}{l}\text { Palvdolstas upp } \\
\text { ( rlindrothoras } \\
\text { sp } \\
\text { Milabra чpp } \\
\text { Pac hnoda чpp } \\
\text { Rhmipta чpp }\end{array}$ & $\begin{array}{l}\text { Iced on } \\
\text { infloresecnee }\end{array}$ & *abuc & & & *. abode & " abcele & tul & & & \\
\hline $\begin{array}{l}\text { Head } \\
\text { catcrpillars }\end{array}$ & $\begin{array}{l}\text { a } \\
b \\
\text { b } \\
\text { d } \\
\text { i }\end{array}$ & $\begin{array}{l}\text { Helacoserpa } \\
\text { armugera Hb } \\
\text { ( ryptoblabs } \\
\text { spp } \\
\text { I ublemma spp } \\
\text { Purodercs } \\
\text { simples Wsin } \\
\text { C clama spp } \\
\text { Nola spp }\end{array}$ & $\begin{array}{l}\text { I arval leed on } \\
\text { developing gralln }\end{array}$ & t.alucdef & ${ }^{*} \mathrm{~d}$ & $\because 1$ & *. ibude & *al & •.1c & ${ }^{*}|x|$ & •abul & •ab \\
\hline
\end{tabular}

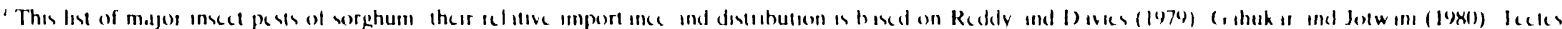

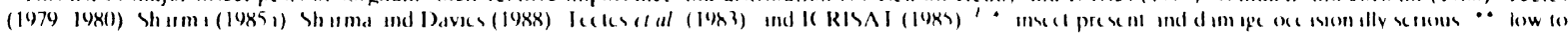

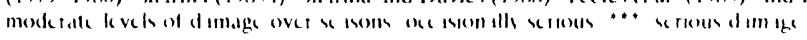

West, I astern and bouthern Afrua ( I able' 2) (Singh e't al, 1968, Starhs, I berhart and Doggett, 1970, Piddhan 1971 Jotwam, 1978 lancla and I cuschnet. 1985a, Singh and Rand, 1986) have shown that most sources of ecsistance to shoot lls originate from the post-1anny season sorghums grown in lndid under stored soll mostutce (ultivals M 31-1 (Is lo54) is 2123. Is 2146 is 4604 . Is 22115 is 56014 and is 18551 have been widely tested, and possess moderate levelo of resistance Some of the improved lines such a I I SV 70)0, IC SV 705 and IC SV 717 developed al IC RISA I have a yeld potental better than the landraces (Agrawal and Abraham. 1985)

Non-pieference for oviposilion is comsideted a d primars mechamem for shoot fle resstance in sotghum bv Kushnananda, Jayadj and Subtamaman (1970), Pradhan (1971), Solo (1974). Sharma e' al (1977). Singh and Naravand (1978), Singh and Jotwan (198(1) Sharma and Rand (1983), Rama et al (1984) and Innithan and Reddy (1985), but under no-chome conditions the resistant and susceptable varietes are equally damaged (Soto, 1974, I anceja and I euschnet. 1985a) Inder glasshouse conditums, none of the varieties ate highly resistant (lotwanl and Srivastava, 1970), and non-preference is substantially reduced with

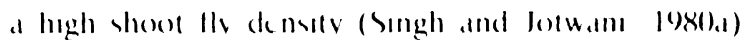

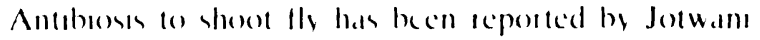
and Saldaslava (1970) Blum (1972) and Solo (1974) sumbal and development were adversely affected when sheot lles were realed on esestamt vartetes

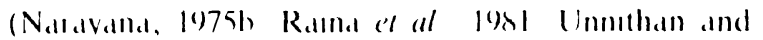
Redde losis compared wilh surecplible genotypes (Songh and Naldy.alla 1978) (mouth and development were ectarded and the latsal and pupal permeds were extended by 815 days on resstant valtedes (Smgh and lotwalli los(l) survival and kecundity were also betler on highls susceptible vitletes (Singh and Naravalla 197h) Afler the maln shoot is killed by shoot fly some sorghum cultivals call produce side tillers that can produce a cedsonable vectel if the plant is not subseguently allateded (Blum, 1972, Doggett, 1972) Survival of tillers and thent development depends upon pumary resstance (Sharma e't al . 1977)

some characters of sorghum seedlings are assoclated with shoot fly ressstance Ihe wild speces of sorghum that ale immune to shoot lly have a high tricheme density on the lower surfice of the leaves (Bapat and Mote, 1982b) Although the direct influence of trichomes on behaviour af the shoot fly reeds to be established, the importance of trichomes on the under- 
Table 2 Sources of resistance to sorghum shoot fly Atherigona sorc 3ta

\begin{tabular}{|c|c|}
\hline Genotspe(s) & Ro'nuths \\
\hline is iston is is is 2023 and is 9613 & 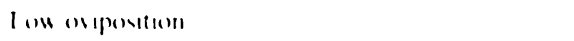 \\
\hline is 422 is 2210 is $|1 k$,$| and is 1034$ & 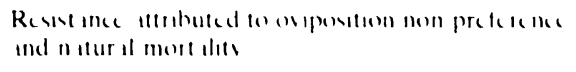 \\
\hline is $1115+(11351)$ & $\operatorname{lon}$ surecptibilus \\
\hline Is 2123 is 4770 and is 11194 & 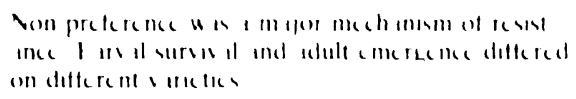 \\
\hline boincr & 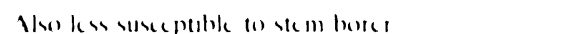 \\
\hline
\end{tabular}

is 1054 is 2260 is 2123 ind is $56(14$

Jhalawat and V ill ahon ig ir

$M 212 B \quad M A l B$ ind $Y / M 2 B$

is $105+$ is 5469 and is 5490

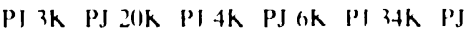
I1) and PI $21 \mathrm{~K}$

PJ $4 \mathrm{R} \times$ shonoli 425 NI) $15 \times$ Imeproved boincr $111 \mathrm{M} 351 \times \mathrm{PJ} 4 \mathrm{R} 22 \mathrm{M} 351 \times \mathrm{PI}$ $4 R 25$ ind $M 351 \times$ Improved solme 1 '

Sorghum parpureo sericelum and s ersicolor

M 351 and BP 53 (IS 1055 )

IS 2146 is 4664 is 546,9 ind is 5490

is 1054 is $58(6)$ and is 5.990

IS 2123 is 5604 is 5490 ind is 8315

Is 4663 is 1776 is 5333 is 8315 and $P(9$

Improved bodner (,M 231 ind is 3922

Is Nos $923 \quad 1034 \quad 1057 \quad 1071 \quad 1082 \quad 1096$

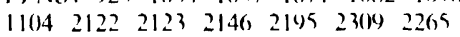
$\begin{array}{llllllll}2269 & 2291 & 23(19 & 2312 & 2394 & 3962 & 4224\end{array}$

$\begin{array}{lllllllll}4646 & 4663 & 4664 & 5072 & 5210 & 5469 & 5470\end{array}$

$\begin{array}{lllllll}5480 & 5484 & 5511 & 5538 & 5566 & 5604 & 5613\end{array}$

$\begin{array}{lllllll}5636 & 5648 & 18366 & 18368 & 18369 & 18471 & \text { ind }\end{array}$ 18551

$365 \mathrm{~A} 3 \quad 367 \mathrm{Al}$ and 366134

Is 5642 is 5490 is 5469 and is 4664

Is 2146 is 3962 and is 5613

\section{Rılım,}

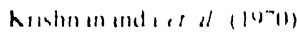

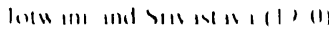

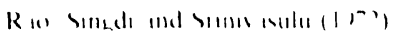

$4(1)(1071)$

(node (11071)

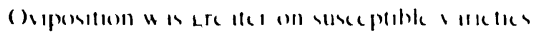

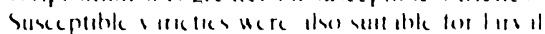

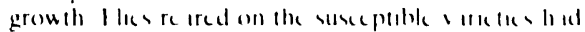
the fic thest tecundits

- 11) de idhe irts

Kundu and Sham I (10)?

R(\)। III

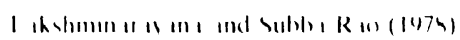

Hehle st wh

Rest int

SII) 11 al (1974)

Mole slumole and Baptl (10)

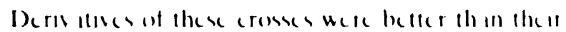
rosist int pirchls

lommune to shoot ils

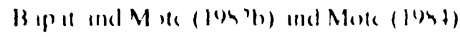

lil'er develepment depends an pum ars mest ume

Kundu Kabore ind Iold in (1977)

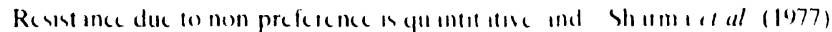
governod by the idditive fenes

Non preferenee w is redeced under stu atoms of he ive inlest ition susceptible holitid ( SH I h id gredtes imounts of sugers mosture ind

chlorophyll I arval ind pupil periods weres 15 diys longer on the esst int lines surviv al ind tecundity wete elversely ilfected ind long and

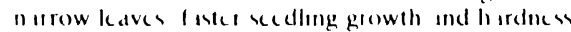
of $k$ it she the were sseceited with resst ince

Resest ince controlled by idditive ind non idelitive gene cffects Heritsbilite 11 «2 2-25 Bapirental

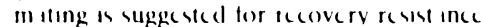
I stumates of genctic gims tic low Inder low intest ition the herttibility cstim iles were higher

Amino ked content is gre tees in resist int lincs Susceptibility to shoot fly is positiole correlited with P' and negetively with lot il phenols

Highly rcsistant

Irichomed and glosse (oxuept is 1034 is 10157 is 4221 is $5(172$ ind is 5511$)$ is 1054 is 1071 is 2394 is 5484 and is 18364 were most stable is 2123 is 2195 is 1664 and is 18551 showed low dam ige and moderat it iblity

Resistant

I ow oviposilion

Non pretercince for oviposition
Mote Kadam and Bapat (1983)

Sh irma and Rana (1983)

Bosth ir ind ( hopde (19801 1981 1982)

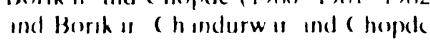
(1) 2 , h)

Khur an a ind Vom a (1982 1983 1985)

Sllunkhe at al (1982)

I inc) I ind I cuschoner (1985,

Raind a $t$ al (1984) 
Table 2 (contınued)

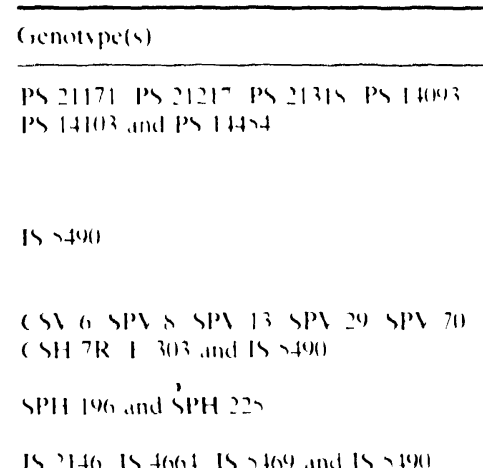

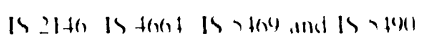

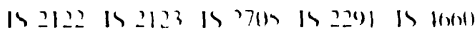

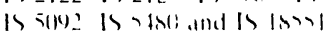

1311101203 . Ind I 3013

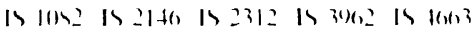
is $46+6$ is $t(6,1)$ is is is and is 7633

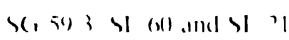

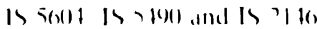

IS 14 in is 71091 and is 12611

$R \backslash V \rightarrow R$, Ind RSI I/R

Is ifo(l and $\mathrm{M}$ is

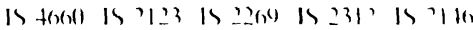

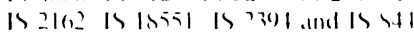

Is lont is 145is is 2123 and Is ind

Pe 6 Ponce $121+211>12$ 2) 33 and 3193

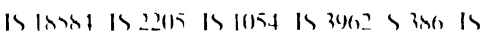

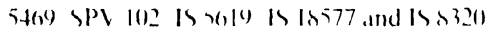

P.4 I $303370 \times 30600 \mathrm{~A} 30, \mathrm{~A} \times 1.4 \mathrm{~K}$ Khed 2 2 40. ( 5 3541 I 30) and is II\%)
Rcmurk

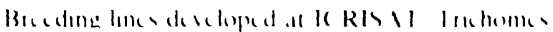

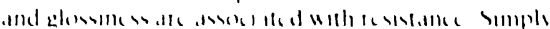

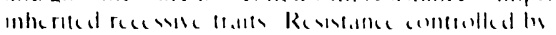

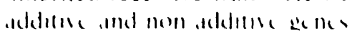

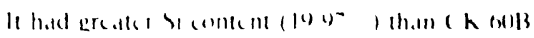
$1110^{-}, 1$

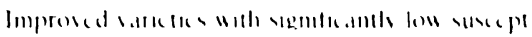

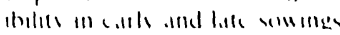

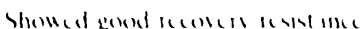

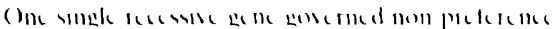

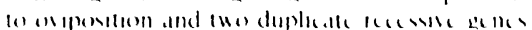

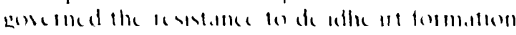

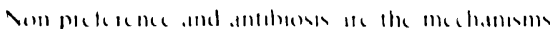

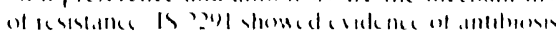

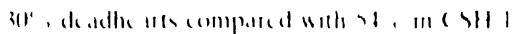

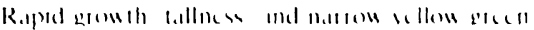

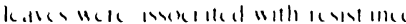

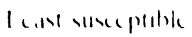

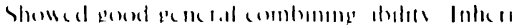

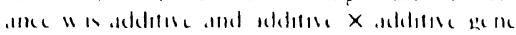
111111

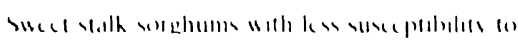
berit 11 s

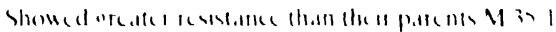
. Ind $S P \backslash$ in

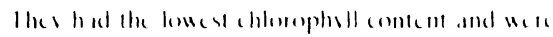
momt rul.,1)t

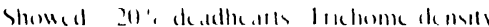

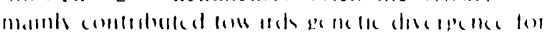

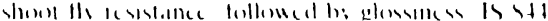

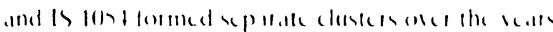

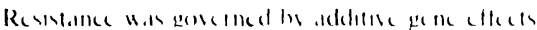

shomed pood tok rome

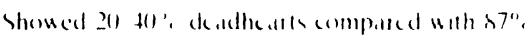

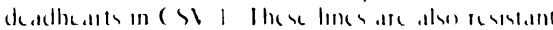
(1) $4 \mathrm{tm}$ bort

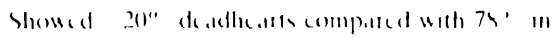
( SHI I
Roterllle

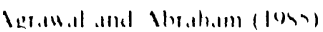

Buthe and Pohlink.11 (19, )

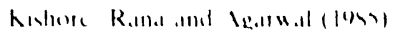

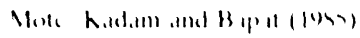

Sh.11111.1 Ind $R$ In.1 (1)

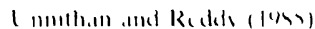

Kahere (1000)

Nlul it al (11)4h)

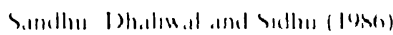

Vimh,11k.11, and 13.1p.11 (1007)

l.11h.11 N101, . Ind 13.1p.11 (194.5)

Mole ant 13.1p 11 (105)

Maik a d al (14)

()man, a al (11)

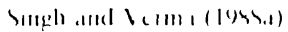

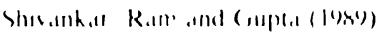

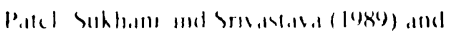
Patcl and suhh :me (I)(N)

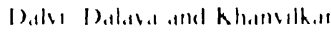

sutace of leaves has been reported by several workers (Blum, 1968, Malt and Bidinger, 1979, Mattr al al . 1980; I ancpa and I cuschnes. 1985a) Most of the lines cesstant to shoot fly also exhibit the glossy kad chatacter during the seedling stage (Blum, 1972. Mant and Badinger, 1979, I aneja and Lexuschner, 1985d, Omorr, Agrawal and House. 1988) (ilossy leaves may possibly affect the quality of light ieflected from ledves and influence the orientation of shoot flies towards therr host plants. (ilossy leaves ma! also influence the host selectern by means of chemeals present in the

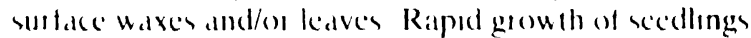
mat retard the fust-mstal lavade form scaheng the growing tup In contrast. slow growith dac lo poor secdling vigour. fou teillity or envirommental stress increases shoot fly incidence ( I aneja and I cuschner, 1985a. Patel and Sukham. 199(1)d Shoot fly-resstant lanes have raped plant growth (Mote, Kadam and Bapat, 1986), greater seedling height and hardness (Singh and Jotwanı. I98/d), and have longer stems and 
mernodes. and shont pedunckes (Pated and suhhams.

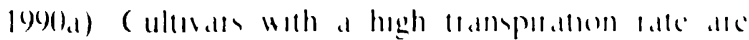

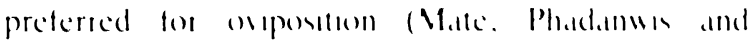

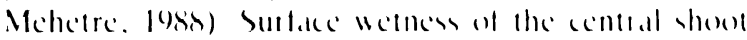
kedt bares between resstant and susceptable genos-

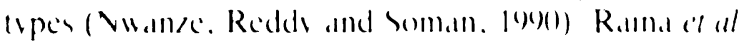
(lysi) reported that kid mosture is important for the mosement of the larta to the groweng pount and deadheatl formatoon bered bochemed studes on

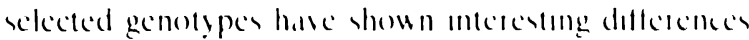
betucen susceptable and ecsatant genotypes. but then

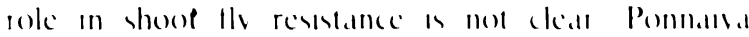
(1951). Blum (1968) and Bothe and Pohhathal (1955)

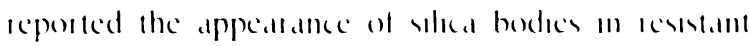

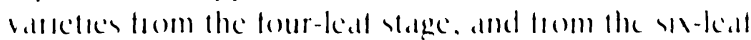
stage on the susceptuble ones fher suggested that the

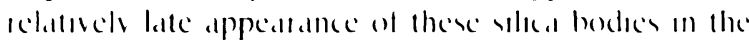
susceptable valtetes makes them prone fo shoot th allach ove a longer perred smolals. He percentage

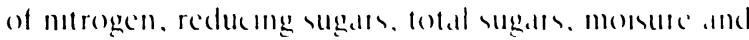
chlorophyll content of kean was heghe m susceptoble

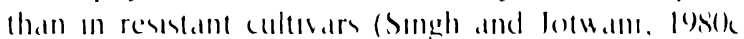

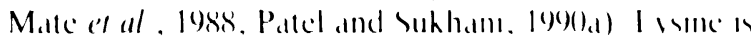
present in the keat sheath of susceptable cultuals but

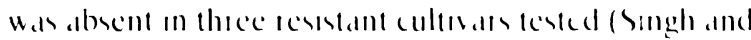

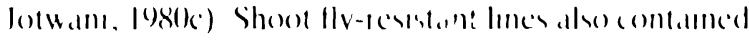
more amomo aceds, phosphorus and total phenols (Khurand and Verma. I9s2, 1983)

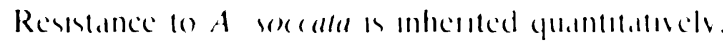
and is predomenantly controlled by addiance an ne actoon (Ralo e'l al, 1974, Balaholaldah et al, 1975, Ralla el al , 1975, Shamma ot al , 1977. Rand, Jotw.1m

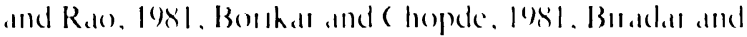
Bomkall. I985, Nimbalhall and Balpal 1987, Smgh and Verma, 1988, 1). whereas Aglalw,al and Abraham (1985)

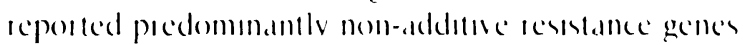

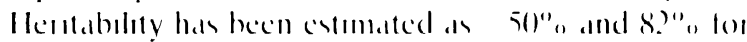
I, and I, generallons, respectareh (Sharma el al

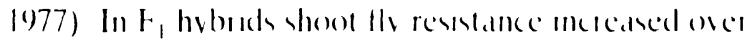

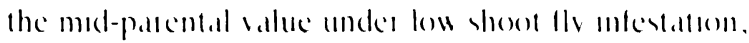

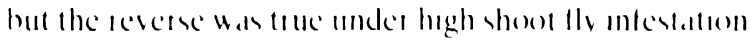
(Shamma and Ralla, I983) I stmalter of genelle (1)effecents of vallabiluts, herllabilat and gente adrance Hese better when shoot Ho intestatlon was optameded (Bomball, (handurwal and (hopde, 1982h) Habnd behaverut was also indealed well be parental perderm.nce (Shalma e't al . 1977)

\section{Stem borers (Chilo partellus Swın. and Busseola fusca (Fuller)}

Resstance to stem borers has been studied in India (Pradhan, 1971, lotwami et al, 1978b, 1979, Singh et al., 1983; Singh and Rand, 1984. 198\%, Srivastavd. 1985; I aneja and I euschner, 1985b, Agadwal and I aneja, 1989). Kenya (Alghalı, 1985. Reddy, 1985), Brazll (I ara et al. 1979), and in southern Afila (Leuschner, 1989) (7able 3) IS 1055 (BP 53), IS 1044, IS 2123, IS 2195, IS 2205. IS 2146 , IS 5469 and IS 18551 show mokedte keds of resstames to yolfed stem

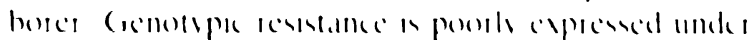

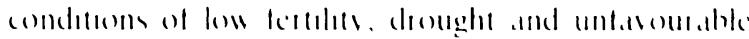

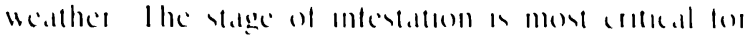

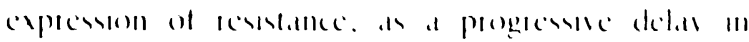

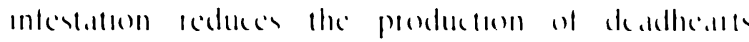

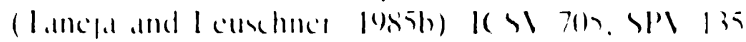

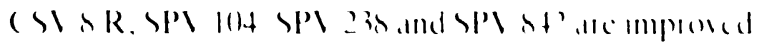

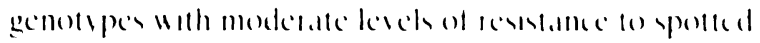
stem boter and with a better veld pertental tham the

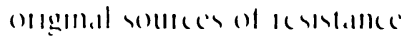

()

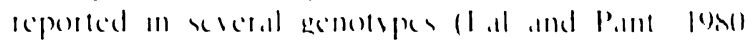

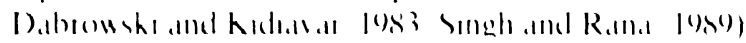

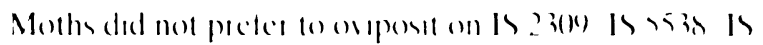

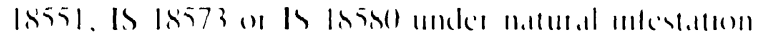

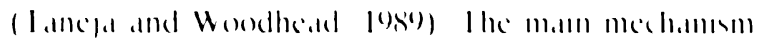

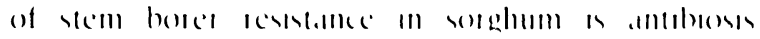

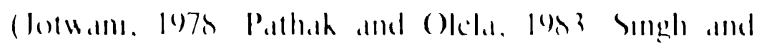

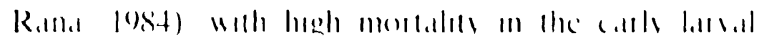

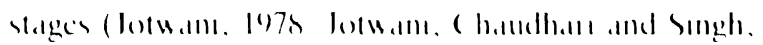

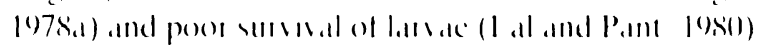

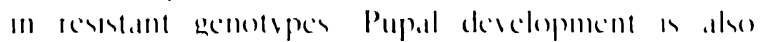

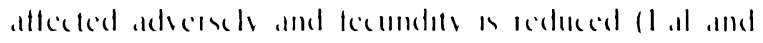

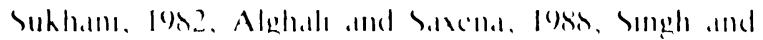

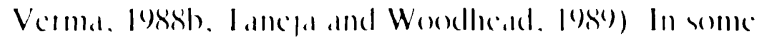

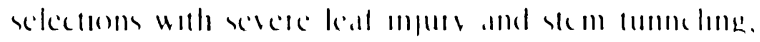

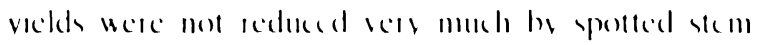

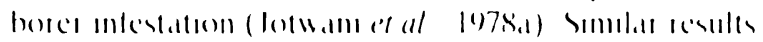

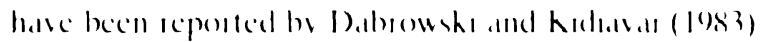
and Nghhalı (1987) in Kinval

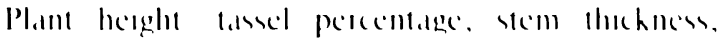

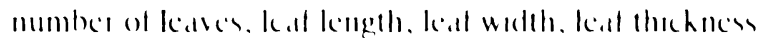
and leat stemeth wese negatmels comblelled wath

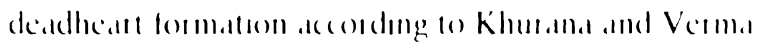

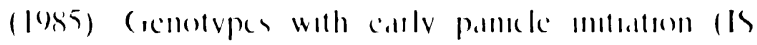

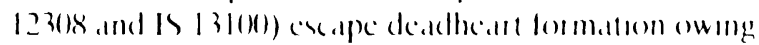

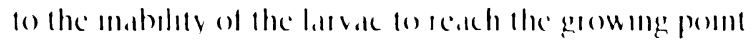

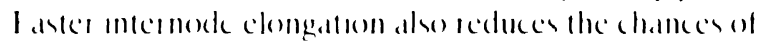
the latva damagung the guowing perme (I anceld and

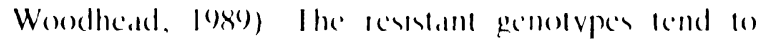
hate a marrou angle betucen the kedt and the stem (Woodhead and Ianc/a. I) 87 ), and the lowere leavers of sorghum are detathed from the culm in some resstamt genotvper the epecuteculal wis and ligulal halls also

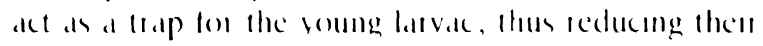

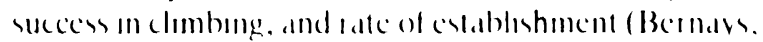
('h.1pman and Woodhead, I983, ( hapman, Woodhead

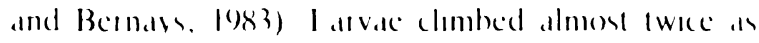
last on stems of is 1151 from wheh the wax had been cemoved, compared with stems belore removal of wals (Bernays e't al. I983) ()thes lactors assochated with stem bores ressstance in sorghum include low sugal content (Suarup and (hatugale. 1962), and gredter amounts of amono deds, lanmms, fotal phenok, neutral detergent hbre (NI)I), atd detergent fibre (AI)P), lignons (Khurana and Verma, 1982, 1983) and slka (Narwal, 1973)

Stem borer resstance is inherited quantitatively (Rana and Murty, 1971, Pathak and ()lela, 1983) but 
Table 3 Sources of resistance to stem borers (Chilo Busseola and Diatr zea)

\begin{tabular}{|c|c|c|}
\hline (unotspu(s) & Remuhs & Retertice \\
\hline \multicolumn{3}{|l|}{ (hal, Bustesla } \\
\hline $1 \mathrm{~m}+777$ & Highls promisms. & 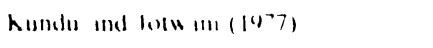 \\
\hline 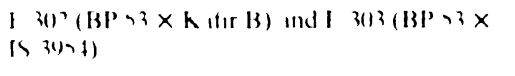 & loke int at un horet & 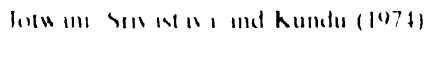 \\
\hline 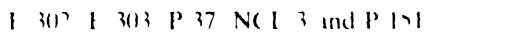 & 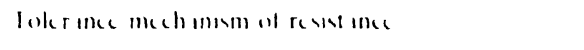 & $\ln (1+1), d d(10-4)$ \\
\hline IS 26 , & 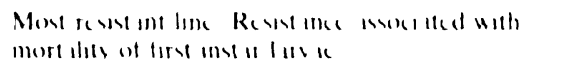 & forw ind (1 d (19) (197) \\
\hline 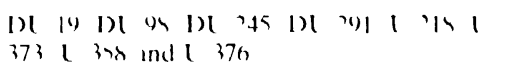 & 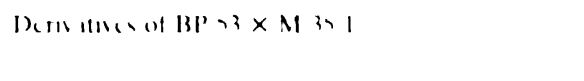 & lotw inu a d $/(1070)$ \\
\hline $\begin{array}{l}\text { D) } 168 \quad 1) 172 \quad 1) 254 \quad 1) 358 \quad 1) 367 \quad \text { ind (1) } \\
3(1,4\end{array}$ & 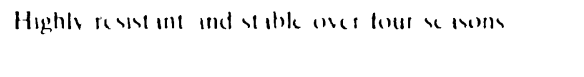 & Smphet al (lus(o) \\
\hline $13(1)$ I) $3(1) 3$ I) $114 \mathrm{md}$ is $430 \mathrm{k}$ & 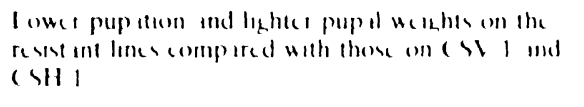 & $1,1 \mathrm{mal}$ suhhm (1M) \\
\hline 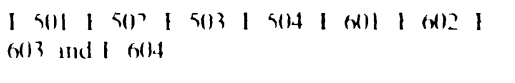 & 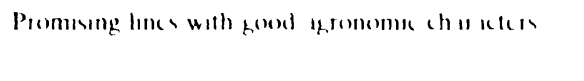 & lutu inl (194) \\
\hline 1302 and 13013 & 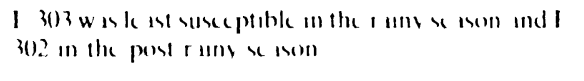 & 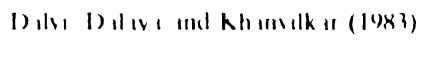 \\
\hline 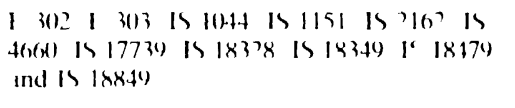 & 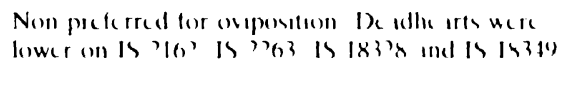 & D)houshe and kulaw (lox3) \\
\hline 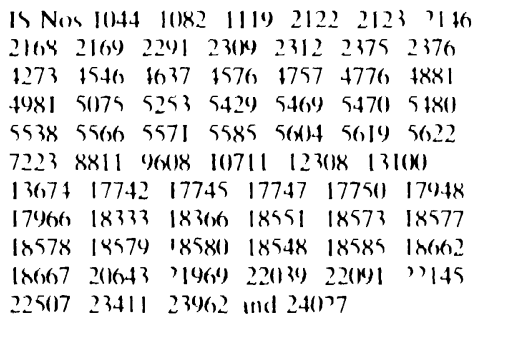 & 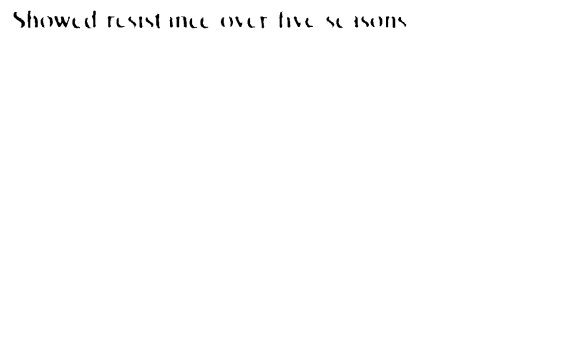 & I me I md I eusehme (I9) \\
\hline I $3(13 \quad 1 \quad 3(0) 15012 \quad 1 \quad 60) 1$ ind I $(0+1$ & 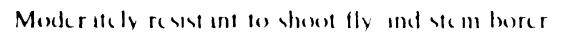 & Mote and $B$ ip il $(14 \times 3)$ \\
\hline $\begin{array}{l}\text { (SV RR SPV } 35 \text { SPV } 103 \text { SPV I H1) ind } \\
\text { SPV 192 }\end{array}$ & Promisml soutces of resist ince & Sill hat al (19)83) \\
\hline 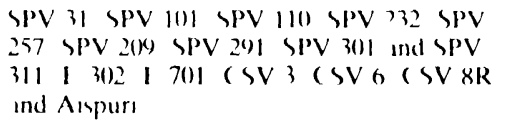 & Non preference for anposition & Singh ind $R$ in i (1984) \\
\hline $\begin{array}{l}\text { C SV } 5 \times(S V 6 \text { ( SV } 4 \times \text { C SV } 4 \text { and } S \text { SV } 5 \\
\times \text { IS } 1664\end{array}$ & 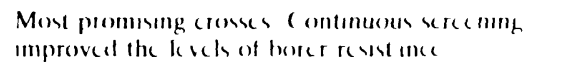 & kxhore t al (1984) \\
\hline $\begin{array}{l}\text { I } 302 \text { SPV } 135 \text { is } 2312 \text { is } 1664 \text { ( SV XR } \\
\text { ind SPV I04 }\end{array}$ & I 302 and SPV 135 are good combuners & 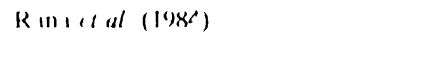 \\
\hline $13(1) 4$ & 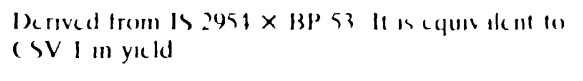 & kundu (19)85) \\
\hline $1(119 / 833$ & Its yeld was not influcenced by borer dim ige & Alh hili (1985) \\
\hline $\begin{array}{l}\text { Is } 1037012 \text { is } 10364 \text { is } 1041 \text { s } 178 \text { is } \\
3962 \text { is } 1213 \text { is } 12897 \text { is } 18479 \text { is } 18326 \\
\text { i } 1 \text { is } 4405 \text { is } 16711 \text { is } 18676 \text { is } 5613 \text { is } \\
\text { is } 17 \text { is } 18323 \text { is } 4881 \text { is } 1151 \text { ind is } \\
18.427\end{array}$ & 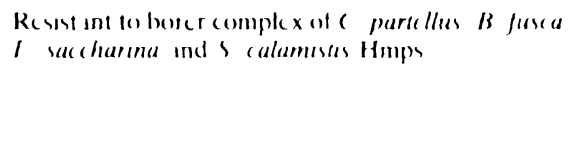 & Redds (1985) \\
\hline Is $2146 \times$ screni & Provided best ch ince to select for resist inee & Pathin (1085) \\
\hline Scron I $(119 / 80) 2$ and $P \mid 01)$ & 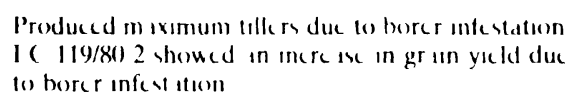 & Alghili (1987) \\
\hline$P 311$ & Resst int & Kahore $(19871)$ \\
\hline
\end{tabular}


Table 3 (contınued)

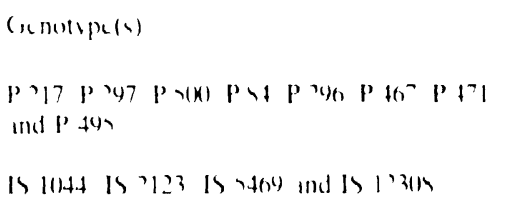

Is ithe and is ?ols

is '1? ind is itor

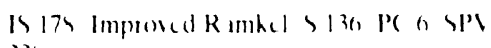

is

I) 140

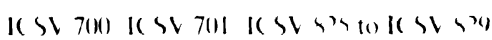

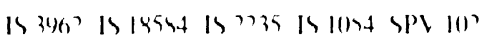
15 $546(0)$ is 2619 is 15477 and P 37
RcIIIh)

RแMt แII

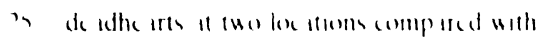

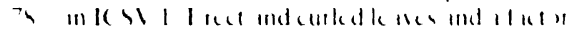

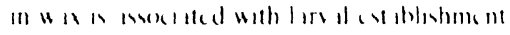

showed intihom

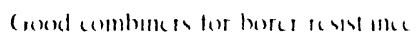

R(s)। IIII

I whadunt

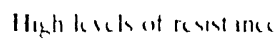

$R($ S) II)t

l)atrata sucharals

If

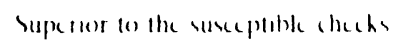

Raknu

hwhell) I)

II whthe at ind I mollin)

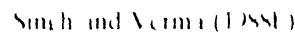

SmLh md h(Im) (1M4)

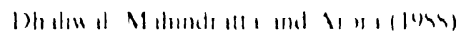

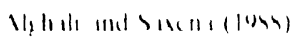

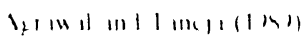

| Il, Ind Suhh mI (1M)

Af $2 h$ and 1177

M6615) (NPI $(64735 \times 1351)$ 84 + Po/ Ru I Ind 787 ?

$1111,11(179)$

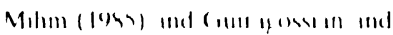
Mhan (10) heratabilaty is low (Singh Jotuan and $R$ and 1940) (sencral combinne abilite is prodommant for hal

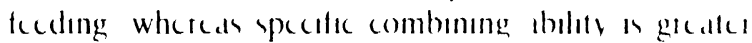
for stcm tunnclling Resistance to katt kecding de id healt formation and stem tunnclling as inherited in difterent ways (Singh at al los P Pithih lo55) stem and peduncle tunnelling ate segnilic intly corclated (Rand at al 1984) Howevet lunnel length has no) corrclation with loss in gidn yicld (Pithatk and ()hela 1983) Additive gene cllcets are predominant for deadheall and hal mpurs (Singh and Verma loyice) For Ostrinta mubulales tib borer damage tadits gence ally had strong negative coriclations with gian vicld (Ross a al 1982) (ontinuous scicemng ovel sevel il

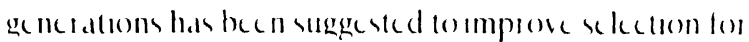
borcr resistance (Kishore Rand and Shama ligk4) F 302 SPV 135 IS 2123 is 5409 SPV 1014 ind Is 4604 are good genctal combincrs (Rand at al lost singh and Verma J Josic)

\section{Aphıds (Schizaphis gramınum Rond Melanaphis saccharı Zehnt and Rhopalosıphum maıdıs Fitch)}

Lxtcnsive screcning for rcsistance to s grammum has been carried out in the USA IS $\delta(1) \mathrm{k} S 30 \mathrm{PI} 26+456$ IAM 2567 SA 7536-1 Ix 2567 and DK 46 arc good sources of resistance (lable 4) FA 266 shows nonpreference an important component of resistance to aphads (Schuster and Starhs 1973) Is 8019 has both tolerance and antibioses whereas PI 202178 and PI 302236 cxhibit all three mechanisms of resistance (Lard Gallı and Busolı 1981) Antibioss has been reportcd also in PI 228928 PI 220248 is 809 PI

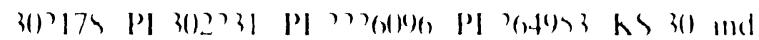

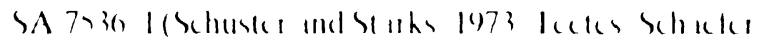

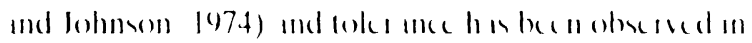

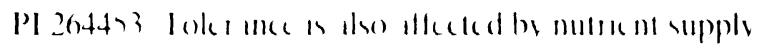
(schuemsing and Wilde 1979) Non prekenes and

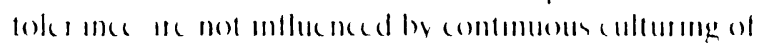

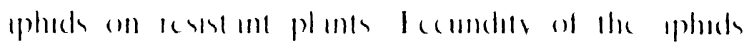

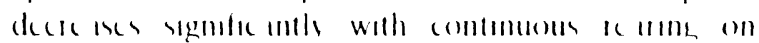

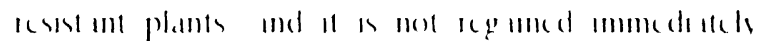

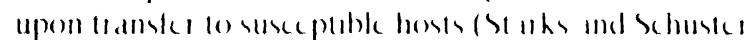

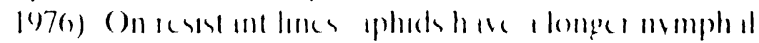

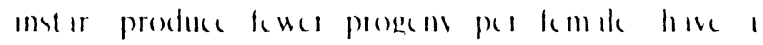

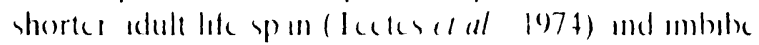

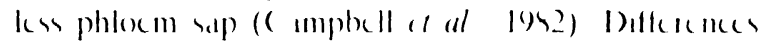
betwecn resstant and susceptible lines incere ise it

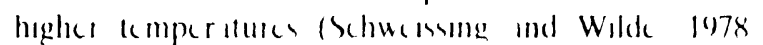
1979) (enotvpes with blocomless ind spere bloxm charactes ile not preferced be the phods (Weabel and

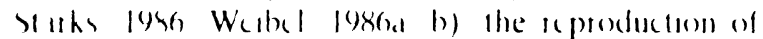

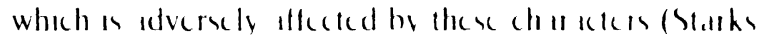
and Webel 1981) I)rexer and (ampbell (1944) suggested that mek ased methwlition of the meddle lamellar pecten honders penctrallon be aphads

lour biotypes of the aphid $R$ mandes have becn identiled but it is 1 sposdede pest with no epparont cffect on gidan yic ld I AM +25 (S (110 9) cxhibuts high levels of resstance to thes iphed whik genotypes 2R in IIB 37 R 12h R 131 R 133 PI 954177 and is

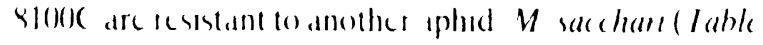
4) Midge resistant lincs Is SV 197 and Is SV 743 are relatively less damaged by $M$ vachar (H ( Sharma unpublishod) Resstance of 2R (PI 257595) is controlled by a single dommant gene (Chang 1981) but it is 
Table 4 Sources of resistance to aphids and mites

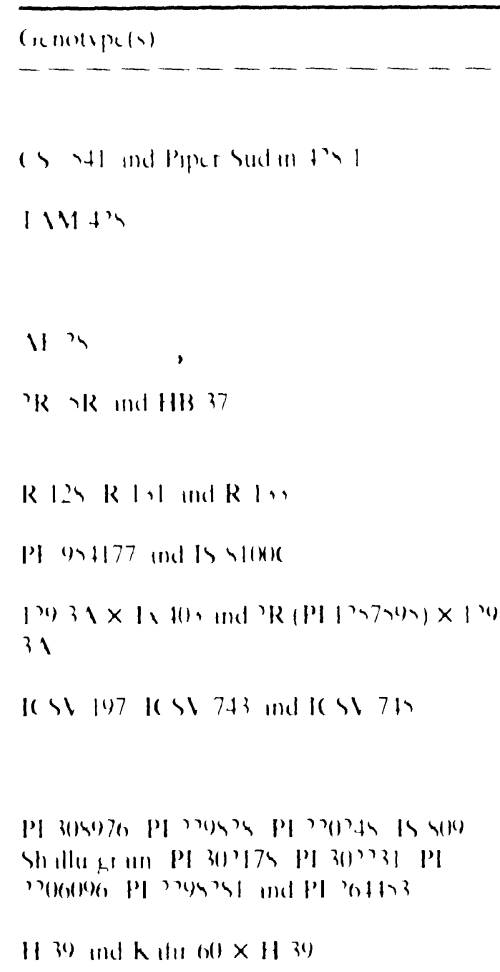

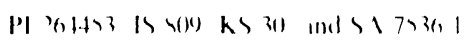

h) $30 \times>\wedge 7>301>A 7>361$ and $P 1$ 26,453

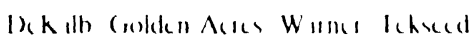
ind Ayptou

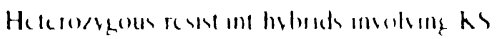
30 Is $50 \%$ and $\$ \wedge 7536,1$ is the source of resst ince

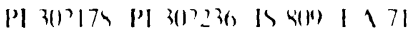
$73(1) 4032$ and $1 \wedge$ ?

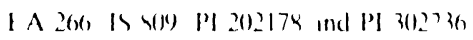

West in (Bm and hm hm) $\mathrm{M}_{\text {inlm }}(B m$ and hh) ind $\mathrm{R}(\mathrm{dl}$ in $(\mathrm{Bm}$ and $\mathrm{h} h)(\mathrm{Bm}=\mathrm{Bl} / \mathrm{s}) \mathrm{m}$

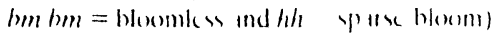

I AM 2567 and is 400

BR 6.tR+ WA 65? and H)(K)R

Ix 2789 to $11 \times 3(x)$

SA 7,361 K 311 is XO19 PI $264453 \mathrm{PI}$ 22(1245 is 923 PI 264452 and $J$ 24?

()k (,P 1110() $\mathrm{k}(, \mathrm{P}) 20$

AOk $8 \mathrm{hm}$ BOK $\times \mathrm{hm}$ A()k $11 \mathrm{hm} \mathrm{BO} \mathrm{k}$ $11 \mathrm{bm} \wedge$ Whe itland $\mathrm{bm} B$ Whe tland $\mathrm{bm}$ $\wedge$ Redlan $\mathrm{hm}$ and $\mathrm{B} \mathrm{R}$ (dl $\mathrm{nl} \mathrm{hm}$

RW D $3 \times$ Weshan 43112 (N) Redbine (x) (N) $R$ ( ombunc $k$ itur $6(1)$ N) Matun(N) Redlan derivatue ( $V)$ SA 7536 I (R) and is $\gamma($ ) $(R)$
Rumirh

- - - - -

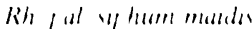

R( SIIIII

Rแ৬! แII

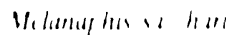

Reखง Int

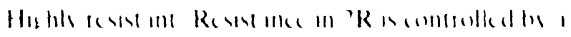
sillk domm int Lent

RLMl «IIt

11 de id redlums

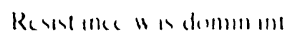

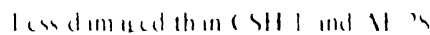

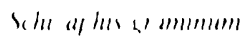

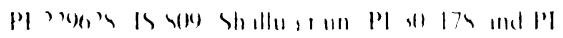

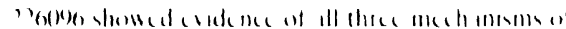

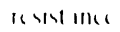

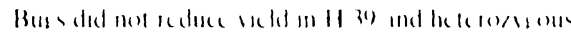

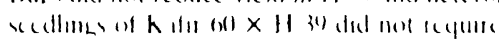
protection

Vonprelend

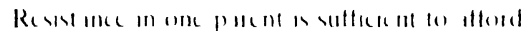

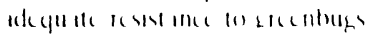

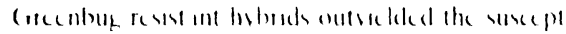
me hbik Rs 670 maks 70 '

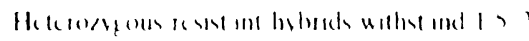

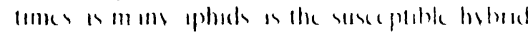

Highls r(s) int

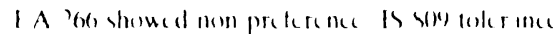

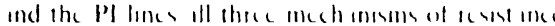

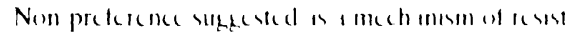
ance in blomile ss serphum

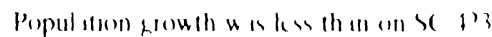

R(u)t int

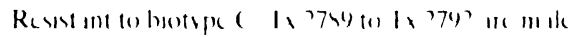
seriles II 11 wasplan

Ros) Int lo howp I

Rosst int blowmless and youse blowm lanes

Bloxmlus lines

Bloumles lines ace non preferred
Rekルllu

$\checkmark 111111111), 11$

ル(t)(11)

$\mid 1111411) 11$

$(11+11|| 1) \mid)$

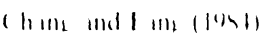

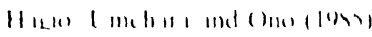

Huh mal P(lMh)

II ( Shum) (uspul ishod)

shimele and stith 11 ,

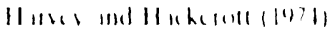

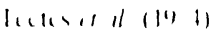

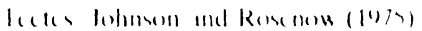

1) P(II Ind Will (1970)

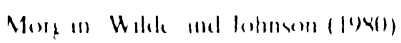

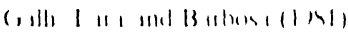

11111,11101

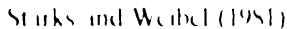

( Implullat al (li)

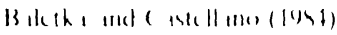

Pelcomelal (19)

St is and Mandluxs)

Wuld (1)

Wubl (1986h)

Wublel ind st inks (19) 
Table 4 Contınued

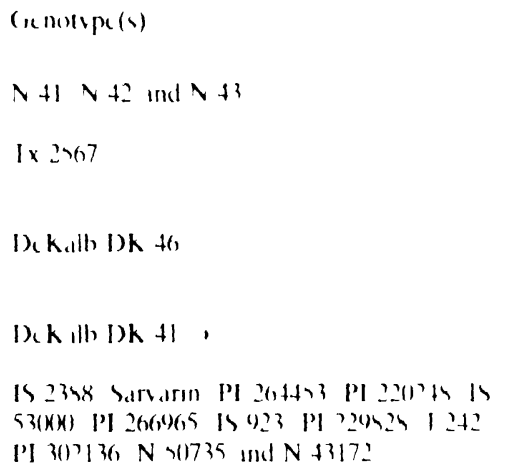

PI 473951 PI $1577(19$ and P 15771

\begin{tabular}{|c|}
\hline 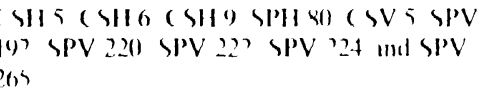 \\
\hline
\end{tabular}

Romirhs

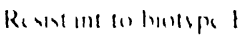

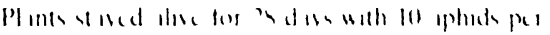

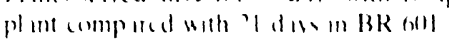

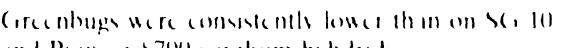

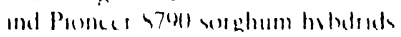

Coconbug restem hibled

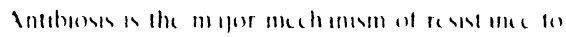

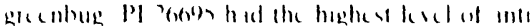

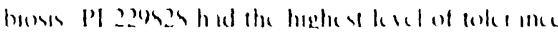

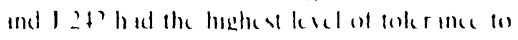
notrpe I

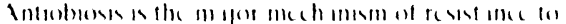

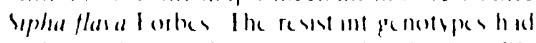

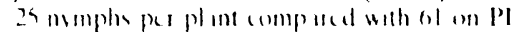
$6,1+43$

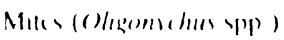

Shoucd foler me

R(M) In!

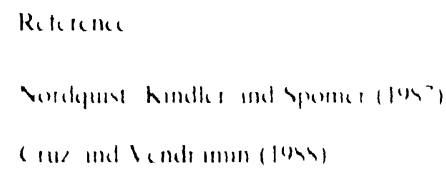

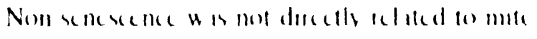
Ic)istance incompletely dommant in II (Ian et al, 1985) Additive and dominance variances are sigmilicant, with the additive factor latger than the dommant lactor for resistance complementary interdetion was suggested in cross $129.3 \mathrm{~A} \times \mathrm{I} \times 403$ (Huch and $\mathrm{Pl}_{1}, 1988$ )

\section{Mite (Oligonychus spp)}

the genotype $\$(599$ to is toledant of mites (t osher et al , 1977) Mite damage has been reported to be lesson late-flowering lines (Perming e't al, 1982), and more on senescing lines (f oster e't al, 1977), but non-senesecence is not directly linked with iessitance to mites (Archer, Bynum and Peterson, 1986)

\section{Shoot bug and chınch bug (Peregrınus maıdıs Ash and Blissus leucopterus Say)}

Lines 1753, H 109, GIB 377B, BP 53, IS 8884, is 8887, IS 8891 and is 8918 are less damaged by the shoot bug (Agarwal, Verma and Bharaj, 1978, H ( Sharma, unpublished) BCK 6()-1155, 1155, S( 3(13, S( 261 and Atlas are resistant to chinch bug sorghum hybrids possessing kafer germplasm exhibit moderate levels of resistance whereds those based on milo cytoplasm are relatively susceptible (Ieetes, 1980) I caves tightly wrapped around the stem have been suggested to be associated with shoot bug resistance in sorghum (Agarwal et al, 1978) the fecundity of chinch bugs feedung on $\mathrm{BC} \mathrm{k} 6011155,11551$ arly Sum.te and $4(30) 3$ is reduced (Wilde and Morgan, 1978, M1/e and Wilde, 1986, b)

\section{Armyworms (Mythımna separata WIk and Spodoptera frugıperda J E Smith)}

Armyworms are sporadie pests, and sesult in extemsive damage on most cercals durmg outhre.aks (Sharma and Davies, 1983) In such sttuallons plant resstance is unlikely to be helptul However, some resstance may be uxchul to restrict a population build up I ince I 302 and 1709 (ressetant to borers) hase becon reposted fo be less damaged by $M$ separala $\$ 10912,1821$ ( $M$. I AM 2566 and NK Savana 5 anc reststant lo Spodeptera frueperda (Iable 5) Antaboses has been reported a a mechamism of resistance an s frugeperda (l ordello, I ara and Pard, I980) I anmon content of gran does not seem to influence the development of tall armyworm larvale (Wiscman at al, 1984), whereas chemeal factors in glumes have a greater effect on larval development (Wiseman at al, 1986)

\section{Sorghum midge (Contarınıa sorghıcola)}

Substantial progress has been made in identification and utiliation of resistance to sorghum midge in Indid (Jotwanı, 1978, Sharma, 1985b, Agrawal, Sharma and I euschner, 1987, Singh, 1987, Sharma et al, 1992b), the USA (Johnson, Rosenow and leetes, 1973, I ectes. 
Table 5 Sources of resistance to leaf-feeding insects

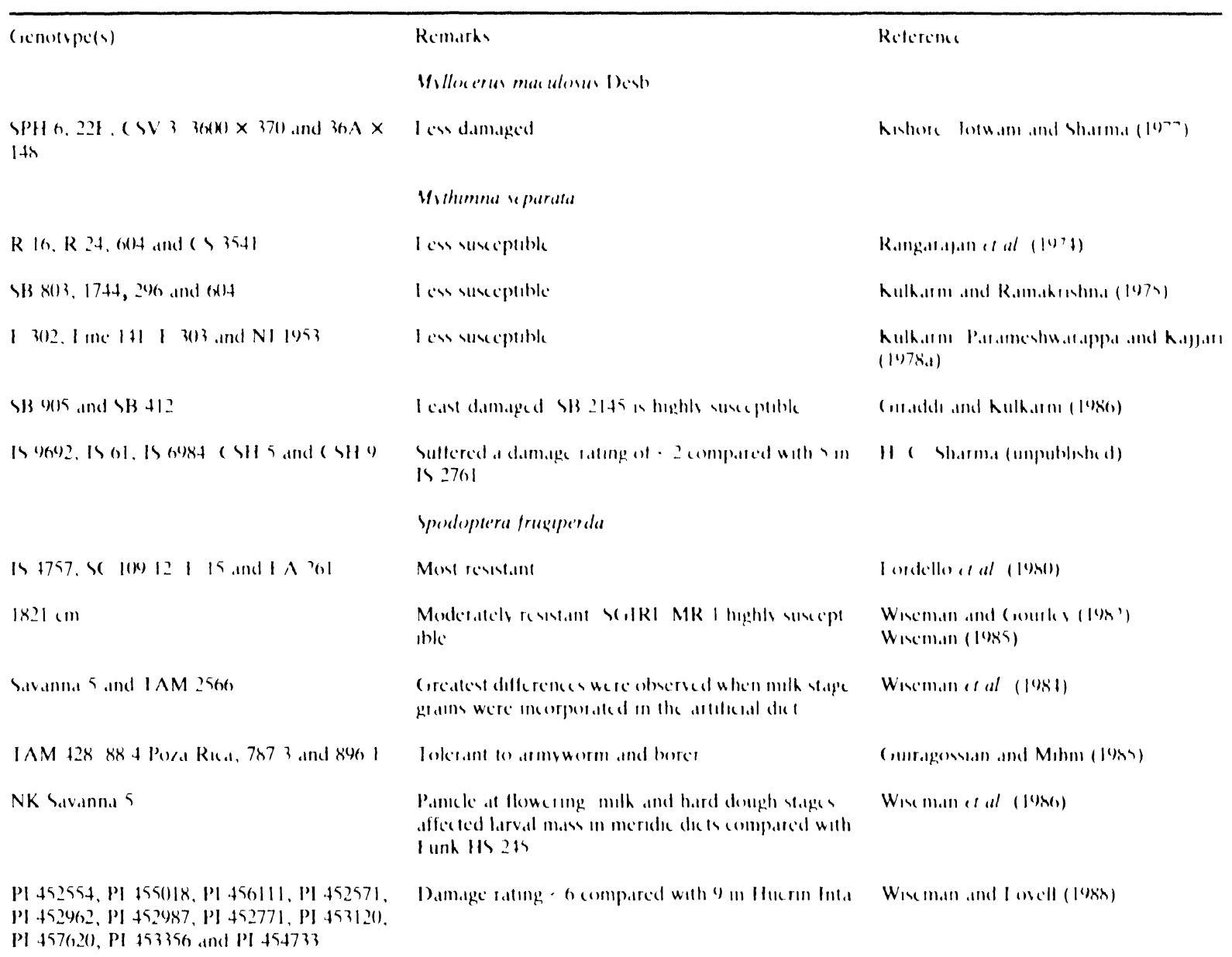

PI 452962, PI 452987, PI 452771, PI 4531201 PI 457620, PI 153356 and Pl 454733

1980, Petcroon et al, 1985a), Australlat (Page, 1979); Franzmann and Page, I984, Passlow, Frambmann and Allsopp, 1985) and Iatun Amencal (Rosscllo, (ioncalves and Dimn, 1975; Reyes, 1985; Rossctlo, 1985). Sorghum midge resstance is also being utilised in brecding programmes in Alrica, Aigentuna and $1 \cdot 1$ Salvador

IS $25790^{\circ}$, IS $126660^{\circ}$, I AM 2566, AI 28, I) 16514 , IS 10712 , litt MR 88 , IS 70015 and IS 8721 are diverse sources of resistance ( able $^{6}$ ). IC SV 197, IC SV 745. ICSV 8801.3 and IC SV $88(1) 32$ have high levels of madge resstance, and then yicld potental is comparable to commercial cultivars Sorghum modge resistance is being transterred to hybrod parents with improved agronoms bachgrounds, and expenmental hybrids are heing tested Ihe use of host-plant resistance in the management of sorghum midge is therefore most promising as the levels of resstance are quite high. These new cultivars will provide greater flexibilaty in sowing tumes to get maximum yields, and proper utulization of avalable ranfall without rosking midge damage.

Non-preference as a mechanism of resstance to sorghum midge was reported by Wiscman and McMillian (1968) and Sharma, Vodyasigar and
I cuschner (lessh) I AM 2506, is I26006 and S(iIRI -MR I werce not pectered by the midges, and sulfered less damage ( $11 \%$. floress with molge larvace) under matural comditums, but S(ilRI-MR-I Mas susceptible under no-chosce condintoms (Shalmatel al, les8b) fewer midge flecs emerged from pancles of resestant cultudrs than from suscepteble onces (lotwant, 1978, Page, 1979. Sharma and I cuschner, 1986, Sharma, I euschner and Vidyasalg,a, I())(f), Sharma, Vidyasagal and I cuschner, 199()h) Resstant cultudas (1). 6514. AI 28. I AM 2560 and is 15107) had lewe

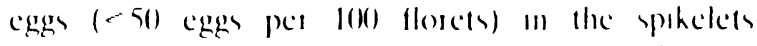
compared with the susceptable chech (SHI I (1.?) ceggs per 10() spoheless) the life cycle of sorghum malge is prolonged by 58 days when redsed on reustant genotypes such as IS 10712 , IS 19474, Is 19512 and IAM 2560

Iactors such as the degree of appostem of glumes (ciecring, 195.3), clecstogamous glumes (Boduen and Neve, 195.3), closed spikelets (Rosscello, Nagal and Overman, 1984) and pancle compactness (Murty and Subramamam, 1978) have been reporled to be asoctatcd with resistance to sorghum madge Susceptibility to sorghum modge is positively and significantly correlated with the length of glumes, lemma, paled, anther and 
Table 6 Sources of resistance to sorghum midge Contarinia sorghicola

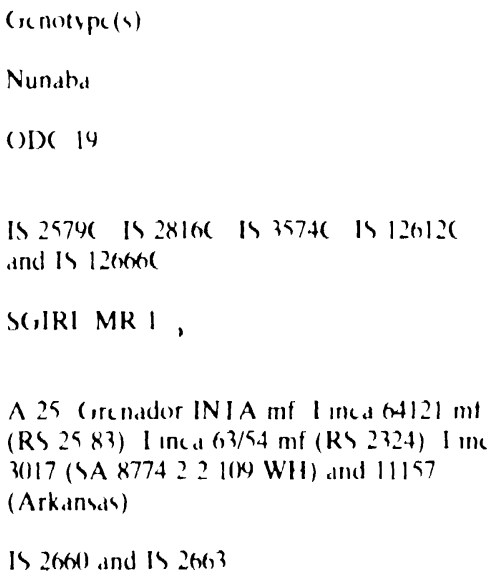

Hurein INTA

AI 28

$1 \times(x) \mathrm{cm} 2321 \mathrm{~cm}$ and $2331 \mathrm{~cm}$

I)J 6514

I ( 92792 F( 92794 and S(,IRI MK I

Is 3472 is 1411 is 4870 is 5977 and is 6170

AI 28

(o) 4 (a) 11 (o) 18 and $K 4$

DJ 6514

AI 28 is $1257($ and is 25086

Is 1260186 and is 126640

I A 73

AF 28

\section{S(,IRI MR I}

$\Lambda 1 \times 2754 \times 1 \times 2767$

is $8100($ and IS 2549

\section{ATx $2755 \times \operatorname{RIX} 2767$ and $A 1 \times 2761 \times$ RTX 2767}

$A \Gamma \times 2755 \times R 1 \times 2767$ and $A I \times 276] \times R \Gamma x$ 2767

AI 28

SG,IRL MR I and PI 383856

$7 \times 2801101 \times 2815$
Remarh)

incidence

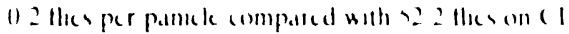
() 3

1).amage tatung \& +5

D.dmage ralling a 5

1) dmage tatumg = 5

( losed glume chat klet

Iolerant of midge

Rosstant to modge

Showed least damage

279, incidenes

- $100^{\circ}$ incidence

- I madge perpanck

3 midges ame rged from AI 28 compalled with 137 252 trom the susecplible hithid $R$ lor)

$10 \%$ incidence

Resistant

AI $2 \lambda$ wa most stable

Sigmiteantly superion to N/pha and $k$ S 19

Highly r(sistant

At least two palls of majer recessege genes dekrmune the resistance

Behaved in a different manner to other parents small glume chadacter was a useful genetke market

Mean vield loss perfemak in the hubrid was () 19g compared with $092 \mathrm{~g}$ for susceptible hobrids

Resistant

Resislant hybrids lost () 32 g of grain per madge compared with 15 g grain per midge in the susceptible hybrid A I $2752 \times \mathrm{RIX} 130$

Midge infested resistant hubrids produced $5(t-6 x) \%$ les progeny per fer ale

Recorded 17 lumes less eggs than Sart

Resistance of SciRI MR I was reccssive and greatle reduced when used as a temalc parent and that of PI $3 \times 3856$ is recessive

Resistant to madg I $28(1)$ (o) Ix $28(13$ arc male stcrilcs in Al cvioplasm

I css midges werc trapped on tt than on $A$ I $\times 2752 \times$ $\mathrm{R} I \times 43(1$
Relerence

Buwden and ven (19) i)

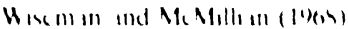

lohmuna a d al $(1)^{-}, 1$

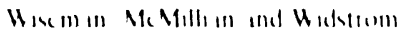
(14)?

Wist in Ma Millin and Unstrom (11)7 1)

Bereyume Rotal ind Milchell (197\$)

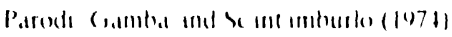

Rouscllo, a al (197)

Wrem in M(Millan and Widstom (1975)

Shi Imsunde , a al (1974)

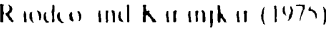

forud, and thent nd 1 in $(1976)$

I if I Rosella ind Igus (1977)

Mutte and Subt tm! tmi im (197x)

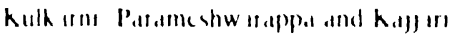
(1)78h)

I ans I in and Veng (1979)

P'se (1979)

Busole and ()sund (1982)

Rossetlo and lgike (1983)

Bowesya Angoon r al (1984)

I ranemann and bage (1981)

Haglot al ( v84)

Hallman lecks and Johnson (1984)

Melton and lectes (1984)

Rossclto it al (1984)

Widstrum a al (1984)

Petersonet al (1985a)

Wayuil rectes and Pcterson (1985) 


\begin{tabular}{|c|c|c|}
\hline$(x$ м) & Rumuhs & Rokrome \\
\hline 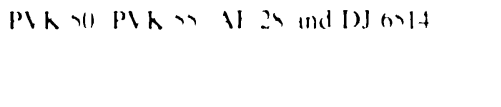 & 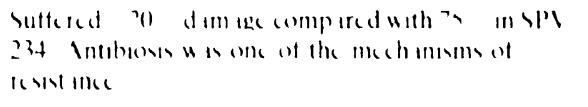 & 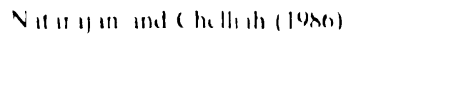 \\
\hline 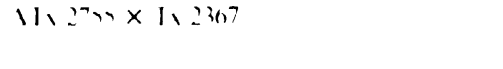 & 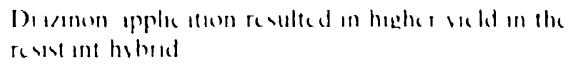 & 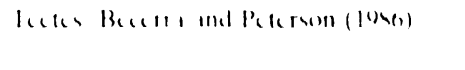 \\
\hline $\begin{array}{c}11,270 \times \times 1 \times 2767 \\
,\end{array}$ & 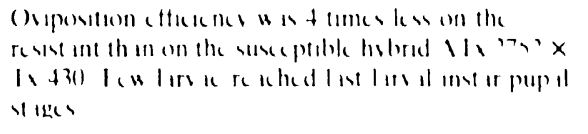 & 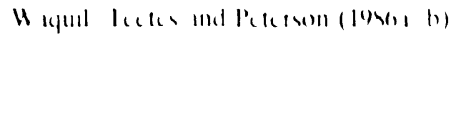 \\
\hline l( ৬) 197 & 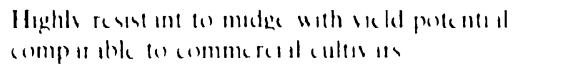 & 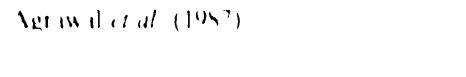 \\
\hline 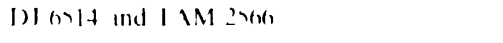 & 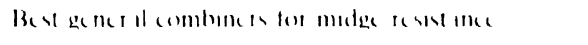 & $1+1,11,1$ al $(104))$ \\
\hline 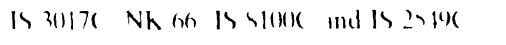 & R(\14) III) & 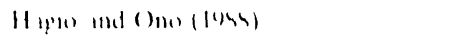 \\
\hline 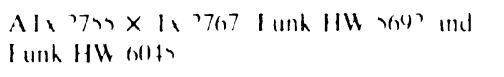 & Showed low susceptubilus te modge & 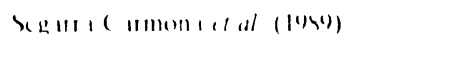 \\
\hline 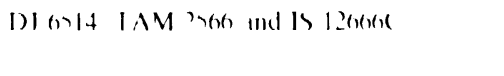 & 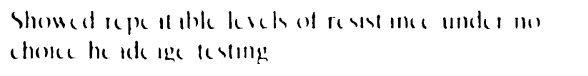 & $\begin{array}{l}\text { Shum! I } \\
\text { (lids) b) }\end{array}$ \\
\hline S(IIRI MR 3 and S(,IRI MIR 1 & 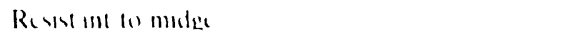 & 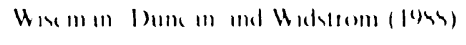 \\
\hline II MR it & 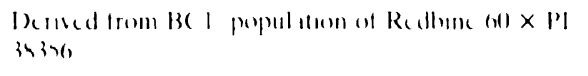 & 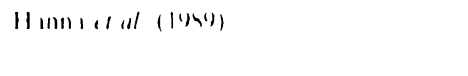 \\
\hline 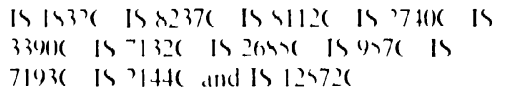 & 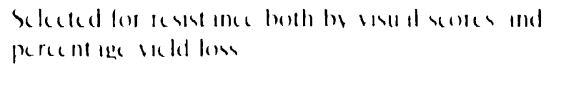 & 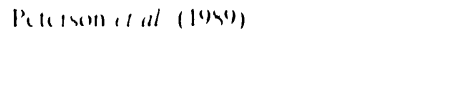 \\
\hline 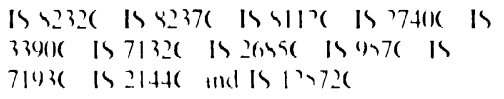 & Resst ant 11 mules & Sh11111(19456) \\
\hline
\end{tabular}

style the rate of gran denclopment betueen the therd

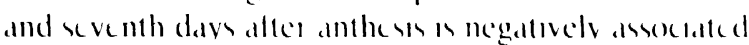
with midge damage (Sharmat el al 199(),a) Shout and teght glumes posible honder axposition and lime the space between glumes and ox.arv for the development of modge latvale bantos and (armo (1974) hale suggested that the tannon content of gran math be one of the lactors impatang resistance to sorghum midge

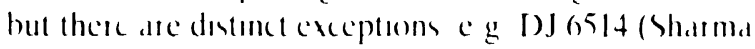
('l al $190(0) \mathrm{a})$

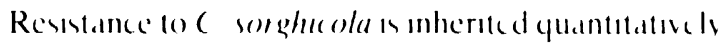
and is controlled by additave genes and some (vto)plasmic elleces (Widstrom. Wreman and McMillian lost Agraual. Abiaham and House 1988) Susceptsbility to midge is completelv or incompletely domunant in some parents At least two pars of recessace genes determine the cesstance of $\mathrm{Al} 28$ and genes with minor effects are also present (Rossetto and Igue 1983) Midge icsistance of lift MR s8 has been reported to be under recessuce gene control (Hanna et al. 1989) S(iIRI-MR-1 and PI 383856 behave in difterent waw and resistance of S(IIRI -MR-1 is lost when used a a female parent (Widstrom et al 1984) Ihe genotypes DJ 6514 and IAM 2566 are good general combiners Both general and specific combinung ability of the parents is important (Patil and Ihombre 1985) as the mean performance of parents and general

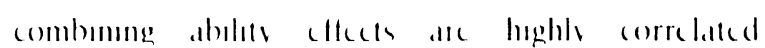
(Agranal a al lysi)

\section{Head bugs (Calocoris angustatus Leth and Eurystylus Immaculatus Odh )}

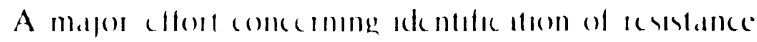
a) head huge has been made in Indad (Sharma 1985e

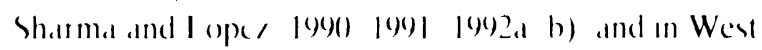

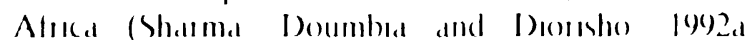

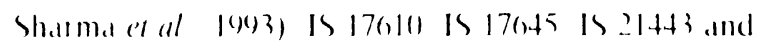

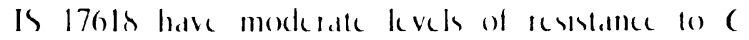
angustatus (lable 7) ( SM 38s S ?) is 14332 Malisor 84-7 and Sakoshad ate good sources of resistance to $I$ immaculatus Most of the sources of resstame have enther colouscd gram/high tammon content of are guinemse sorghums from West Africa Malseos it 7 a line dersucd from germense sorghums has a moderale vicld potental and is medium duat in height with d good grann qualite It can be cultuvated in areas endemic to bugs in West Africa and also used in a resistance breeding programme

is 2761 , is 17610 . Is 17618 and is 17645 were not prefered by the bugs in labotatore tests (Shatma and I opez. 199(1) Under cage conditions, nune egges per 1(0) spikelets were recorded in is 17610 compared with 129 eggs per 100) spikelets in (SH 5 (Sharma and I oper. 
Table 7 Sources of resistance to sorghum head bugs

(renotspe(s)

( hencholam

is 2761 is 9692 is 9639 is 6949 is 176101 is 176 it and is 1764)

is 17610 is 1761 and is $176+45$

is 17610 is 176,18 is 17645 is ? 1443 is 21444 is 14940 is 201609 is 199.49 is 14950 is 19457 is $2(x)$ the is 25760 and is 27329

$$
\text { Remirh、 }
$$

(alesoms ansurusum

supportad low popul itroms

supportad lows he ad bug numbers ind ar sutfered

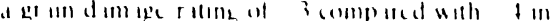
the surecptihle cultus is ( SH)

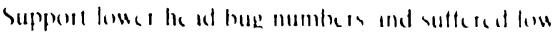

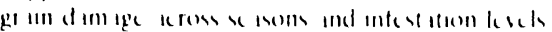

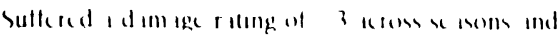
under he akdge comditum compered with a

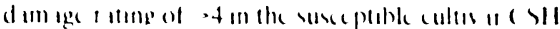

lar)s/us Immas ulatus
Rutumu

B | (1)

Sh 11III 1 (14h)

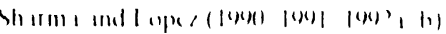

Sham) mll (1)

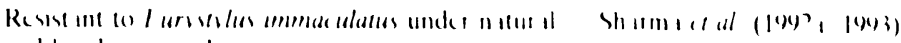

IS 14332 Malisor 8.47 ( SM 38x 529 sikoika and kambounse local and be adk age condicoms
1990) ( ultivar non-preference is also a component of resistance to Lurmelus Is 14332, ('SM 388. Malisor 84-7, 83F6-16 and 831 6-111 had less than five females per pancle compared with 11 females per panicle in I 35-1 under free-chose conditions in the field I he nonpreference of (SM 388 ha also been confirmed in laboratory cage tests (Sharma et al, 1993) Postembryonic development of (' angustatus is prolonged by 1-2 days on IS 17610, Is 17618 and is 17645 Survival and establishment of first-mstar nymphs is relatively lower on is 17645 than on the susceptable checks, (SH 1 and CSII 5 (Sharma, 1985 , Sharma and I oper, 1990) (isowth rate and efficiency of conversion of ingested food into body matter are lower on is 6984 and IS 2761 than on CSH 5 (Sharma, 1985)

Balasubramanan et al (1979) reported that cultivars with loose panicles are less susceptible to head bugs (irann damage and bug population increase are pesitively associated with panicle compactness (Sharma, 1985e, Shatma et al, 1993) However, under hedvy levels of head hug density, severe gran damage of genotypes with loose pamcles could be due to othet lactors (ultivars less susceptible to ( angustatus tend to have long, hard and less hary glumes (Sharma, 1985C) Dass to glume openong (>20) (days from anthess), longer glumes ( $>5 \mathrm{~mm}),>50 \%$ of the gran surface covered by the glumes, hard corneous graın, and possibly quicker grain ripening, all contribute towards resistance to $\Gamma$ immaculatus (Sharma et al, 1993)

\section{Head caterpıllars (Helıcoverpa armigera $\mathrm{Hb}$ )}

Resistance to head caterpillas has not been studied specifically, although some lines sutfering less damage have been reported (hencholam, SPV 130, SPV 69 SPV 9, RS 160 and $K$ Iall are resmlant to head caterpillars (Wilson, 1976, Baldsubramanian et al, 1979, Natardjan and Babu, 1988) Genotypes with loose panicles suffer little damage by head caterpillars, possibly because of cast acess an pardistends and predators (Balasubramaman at al 1974) Ihe abilaty to combune factors for resstance to hedd catcipillas has been studied hy Patce al al (1986)

\section{Effect of insect-resistant cultivars on population dynamics and economic thresholds}

Adequate levels of ressstance are present agdanst only a lew sorghum pests sorghum madge and aphids However, varieties with low to moderate levels of resestance agamst shoot fly, stem borces, le ad hugs and armyworms can be very useful for pest suppression over a period of tame the adverse effects of resistant genotypes on pest populatoms are contonuous, cumu lative and without costs to the farmess, whereds pesticides require money and their effect on pest populations declines over tame, so they may requare a application Reduction in pest demsity through plant resistance also can assist (ontrol with natural enemes and reduces the number of pesticide treatments that may be needed A reduction of the rate at which the pest populations increase will delay the atlanment by the insect of an economic threshold level (I II) I his is espectally true if the resselance mechanisms increase the mortality of immature stages and prolong the developmental period of survivors I he delay may also prevent the insect population reaching an I II until after the most susceptable stage of the crop, thus climinating the need for any insecticide use (Overall, the use of host-plant resistance in IPM conserves natural enemies, preserves environmental quality, and slows down the rate of development of insecticideresistant insect populations

\section{Effect of host-plant resistance on economic thresholds (ETL)}

The effect of insect-resistant cultivars on threshold levels will depend on the nature of resistance and the 
criterion on which the theshold a based It the I II w based on damage fe ge percentage of deadhears for shoot th and sembores number of keanderamaged bs aphas or perecontage kat area comsumed be armworms) and the majot component of resstance is tolerance non-preterence and antebeses (as in shoset fls stem bosers. gecenbug. aphads, armusoms ate ) then economk damage will be suflered be a susceptuble cultuda in Juls, a moderatels resstant cultural in August and a cesstant cultu, ar be the end of the seasun

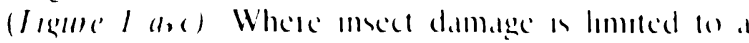
pattecular stage and one a short pernod le g deadheart formatron due to shoot the and stem boter), the dater when a cultude can be sown will depend on me lex of cesstance I hus a susceptshle cultads such a ( sll I cannof be sown atter lune
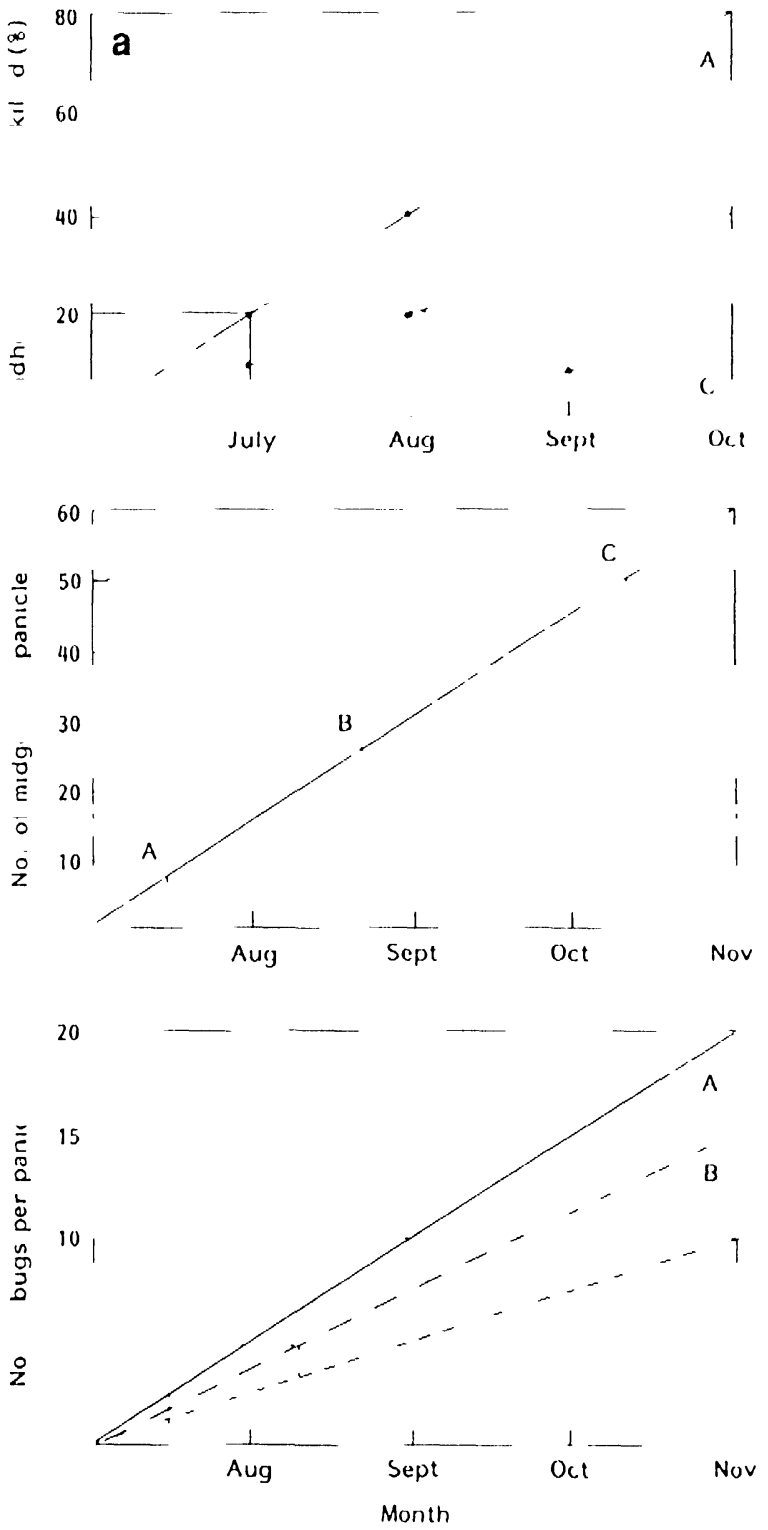

Figure 1 Effect of host plant resistance on economic threshold level (ETL) when the ETL is based on (a) damage, (b) non damaging adult stage and (c) damaging adults on genotypes with non-preference and antibiosis $A, B$, and $C$ are susceptible, moderately resistant and resistant genotypes, respectively
It the I II a based on adults that do mot d.am,age the

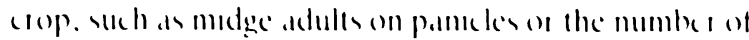
mothe collght in pheromone or leht traps, the 111 will be hegher with an mereane in the level of imser cestance the 1 ll of sorghum molec mat be las

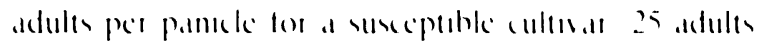

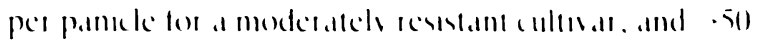

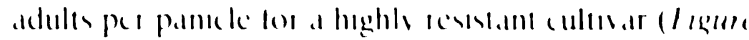

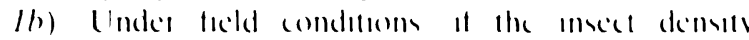

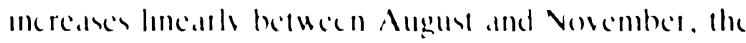

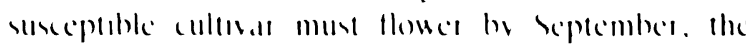

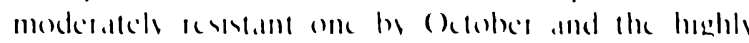

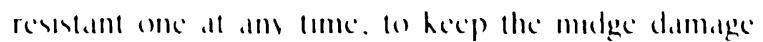

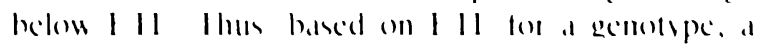

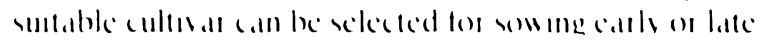

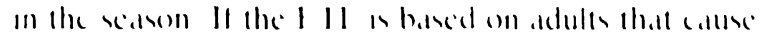
damige (o ge head hugs). and the mehamem of

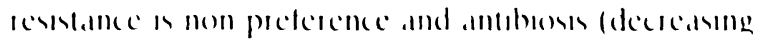

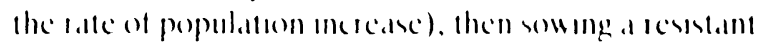

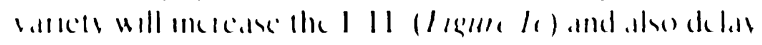
when it is atlanned

\section{Effect of plant resistance on insect density/yield loss relationshıp}

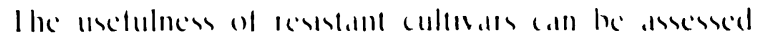

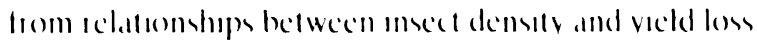

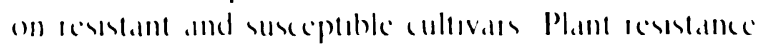

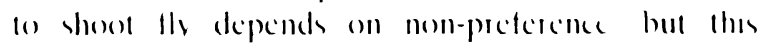

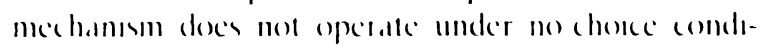
forms of under stluatloms of high pest demsils Ior all

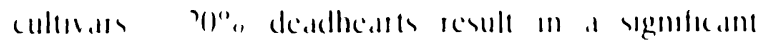

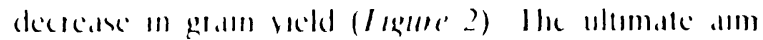

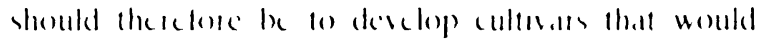

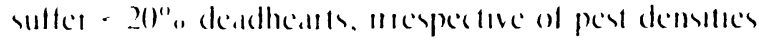

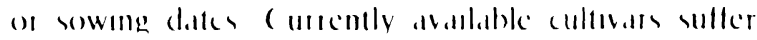

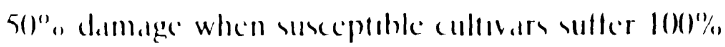
(lamage

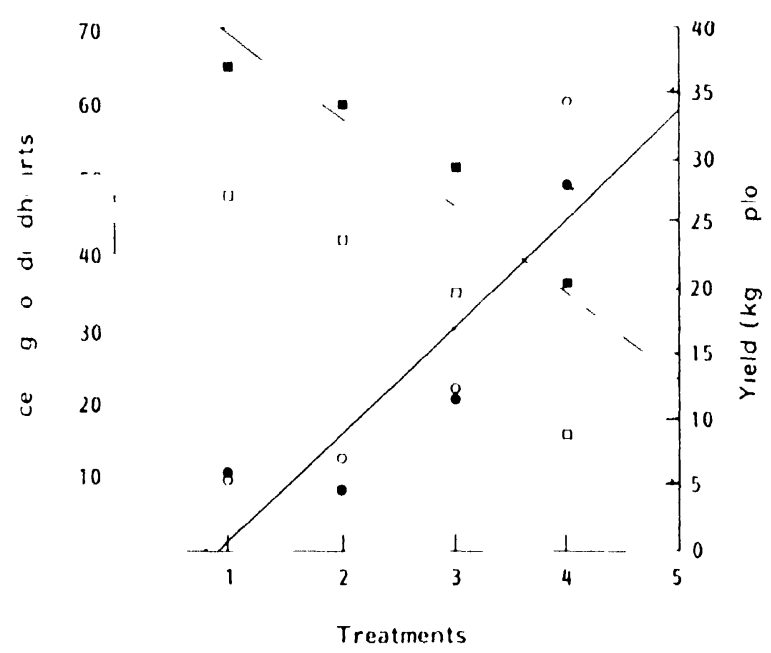

Figure 2 Effect of different levels of protection (treatments 1-4) on shoot fly deadhearts and grain yield in the susceptible cultivar $\mathrm{CSH} 1$ during 1983-84 Percentage deadhearts,

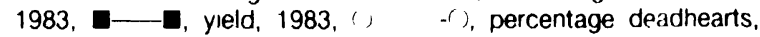
1984, '1 - i yield, 1984 (S L Taneja, personal communication) 


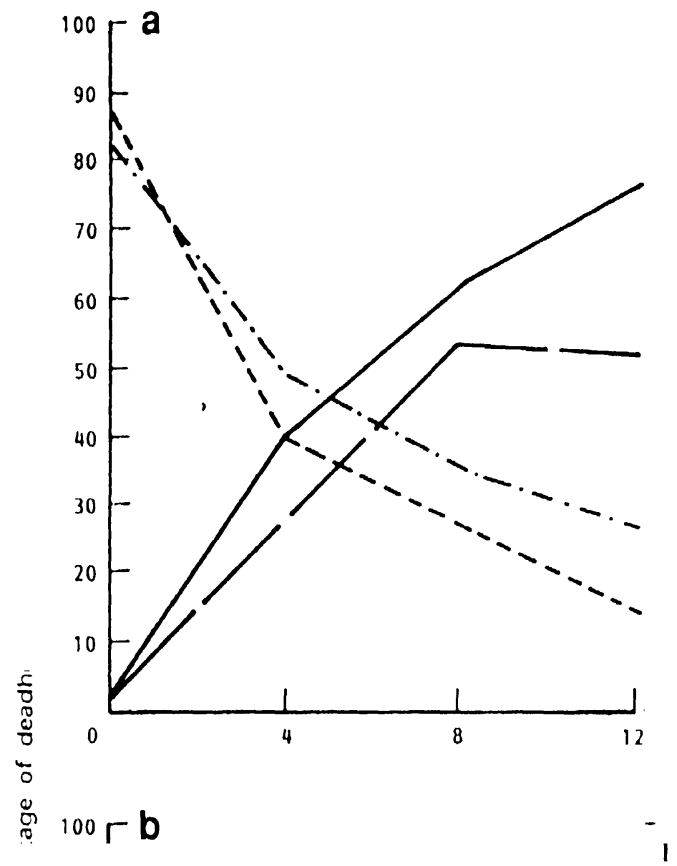

90<smiles>CC</smiles>

70

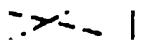

60

50

40

0

4

8

12

Borer density (larvae per plant)

Figure 3 Effect of number of larvae per plant on deadheart formation and graın yıeld (a) 20 and (b) 40 days after emergence (Taneja and Nwanze, 1989) ___._... Yield of resistant cultivar, - - y yeld of susceptible cultıvar, - - - percentage of deadhearts on susceptible cultivar, _- _ - percentage of deadhearts on resistant cultivar

With o' partellus. the stuatson is almost smalar to that of shoot fly, except that the pest can complete 34 gencrattons on a single crop compared with only one shoot fly generation. I hus, even low levels of ecsistance can have a greater cumulative effect in reducing pest populations. The extent of damage (deadheart formatoon) is greatly influenced by the timng of infestation (Figure 3) (iscater damage and yield loss can occur 21 ) days after crop emergence compared with 4 () days after crop emergence Under a heavy infestation (12 larvac per plant), a resistant cultivar yields more than a susceptible cultivar whereas the reverse can occur without borer infestation
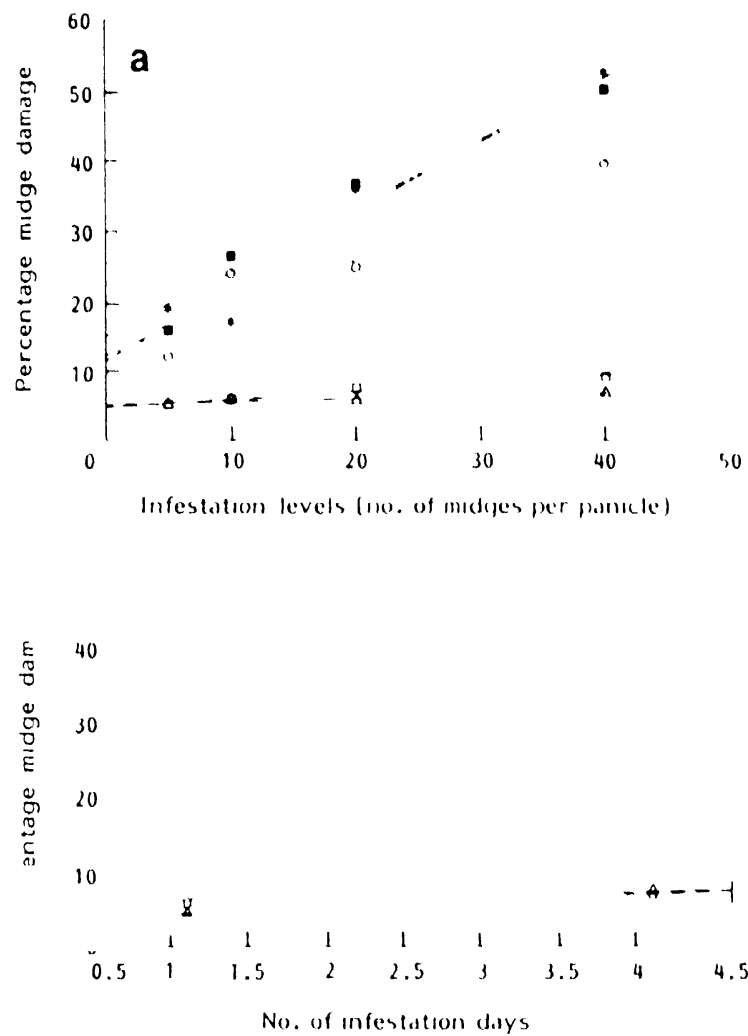

Figure 4 Fffect of (a) insect density (no of midges per panicle) and (b) number of infestation days on midge damage in five sorghum genotypes resistant cultivars ICSV 197 (1) and ICSV 745 (/), susceptible cultivars ICSV 1 ( ) ICSV $112($.$) and CSH 1$ (a) (H C Sharma, unpublished)

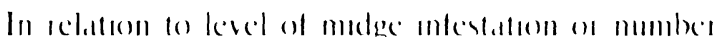

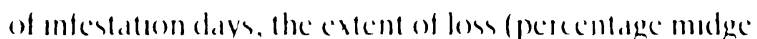

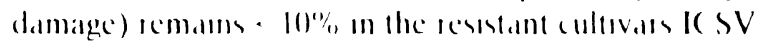
197 and ICSV 745 compated with a lincin metcisce in damage in the susceptable culturas ( SHI I, I S SV I and ICSV II2 (Irgure t) At five molges per pancle, the suscepteble cultuars lose $1020 \%$, ghan yedel companced with - 4\%, In the reststant cultuvas Ihus, molgeessetant cultuars can be soun irrespective of pest denstices without sufferang a semil:cant loss in gran yicld

Bug numbers remamn substantially lower across stages of pancle development on a Iessetant cultevar (IS 21443) comparced with a susceptible cultovar (c) SII 11) (Fegure 5) At the dough stage. these were 824 bugs per five panteles in (SH 11 spralyed four limes with demeton-()-methyl compated with eight bugs per five pancles in the resstant cultivar IS 2144.3 Yicld potental of the susceptible hybrid is much greater than that of the resstant cultivars, but a very low level of head bug damage can render the grain unfit for human consumptoon (Sharma and lopes, 1989) loss in gran yield in (SH 11 due to head bugs is 31 ha ' compared with $0.74 \mathrm{t}$ hal for IS 21443. Currently avallahle sources of ressstance to bugs reduce the rate of increase in bug populatoons, resultung in less loss of grain yicld and quality 


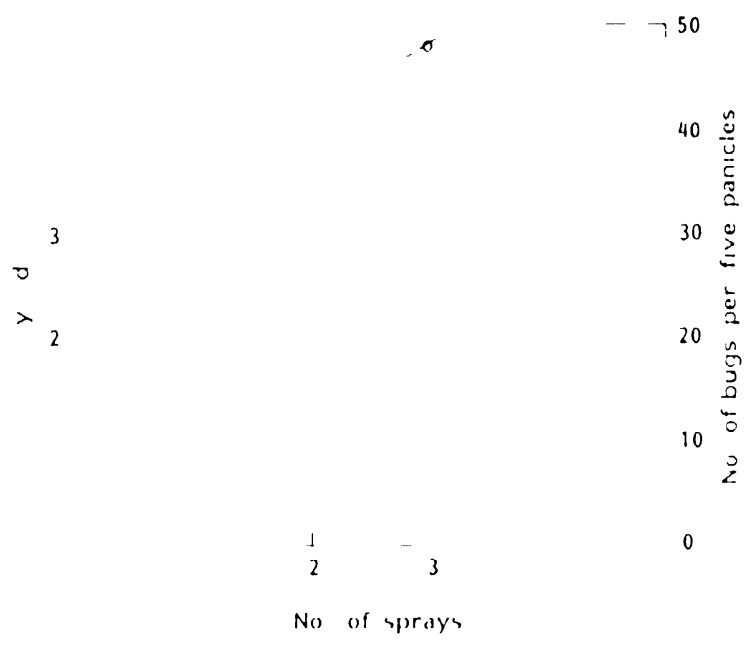

Figure 5 Effect of different levels of protection (no of sprays) on head bug numbers (closed symbols) and gran yield (open symbols) in a resistant (IS 21443 ) and a susceptible cultivar (CSH $11 \rightleftharpoons)$ (H C Sharma unpublished)

\section{Host-plant resistance as a component of IPM in sorghum in different agroecosystems}

Ihe mond aceptathe form of IPM Imboles the are of

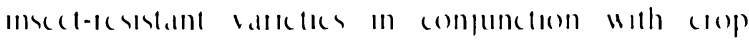

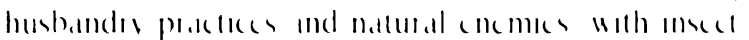

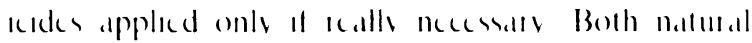

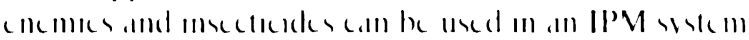

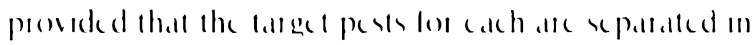
space (c ge reot keding pests such as whike erubs

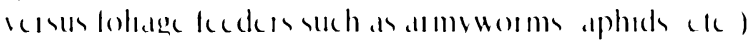

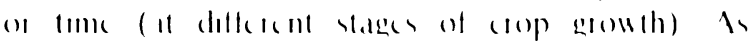

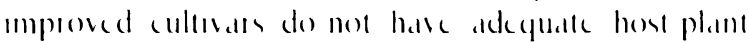

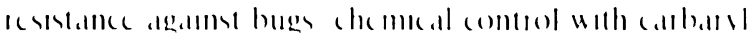

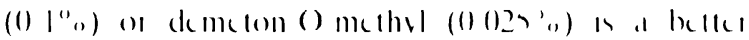

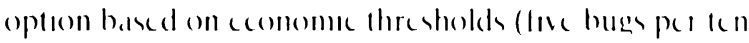
pancks al hall inthess) (shamma and I cuschonel 1987 shamma and I oper 1989) In thes stluallon nallutal encmes an he combmed with modelale kuck

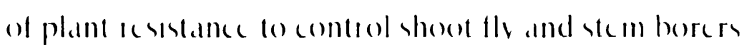

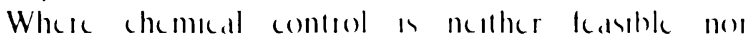
conomeal restatance to her pestshas to be sullecentle high to aroid pestecke use and conseme the matural comes

The role of host-plant esestance for pest mandeg mont in diflerent agencesistems is discussed below

\section{South Asıa}

Durng the rame casone tomels sounge of the same

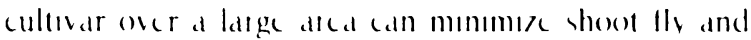
modge damage I hes will help decrease the imsect

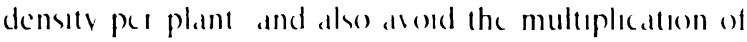
the pest that occurs on sequentially sown crops Where other insects such as stem borers armvuorms and head bues are also important a need-based insecticide mas

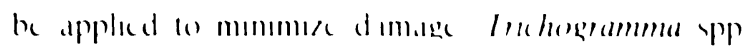

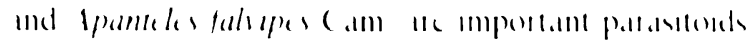

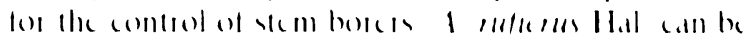

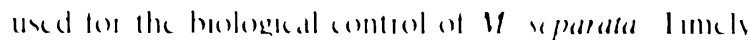

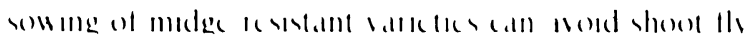

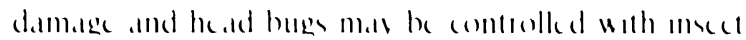

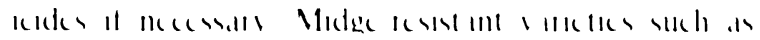

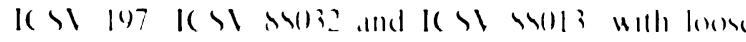

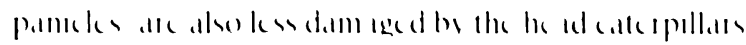

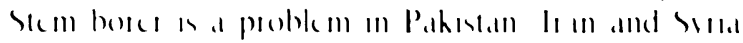

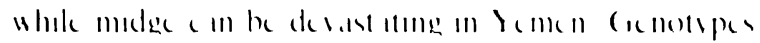

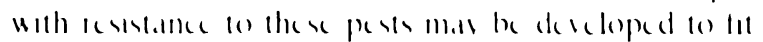

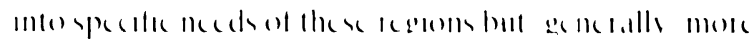

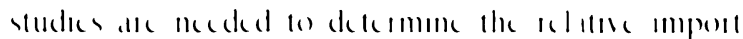

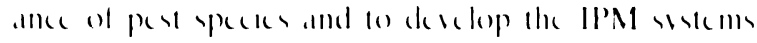
ic(u) (1)mels

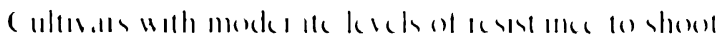

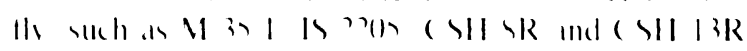

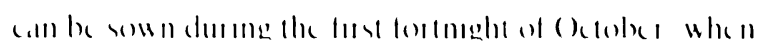

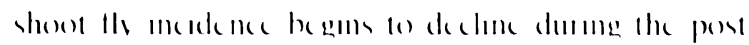

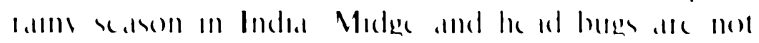

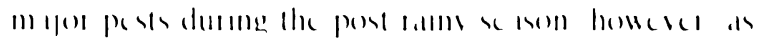

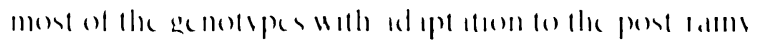

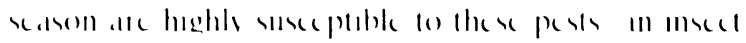

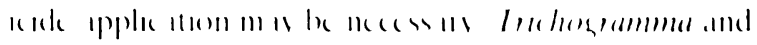

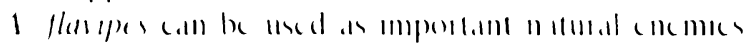
mallus hores

\section{South East Asıa}

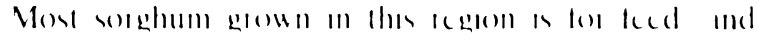

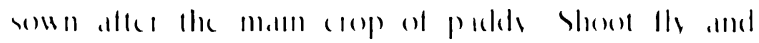

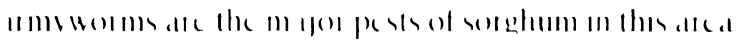

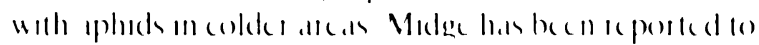
be 1 problem in the Philippume l.1p in ( hom, and

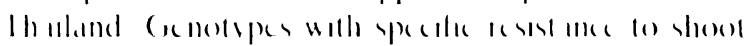

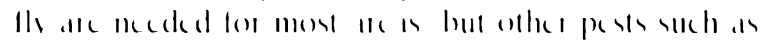

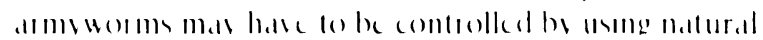

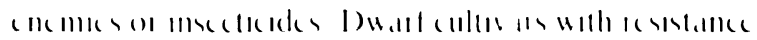

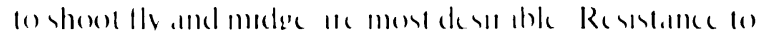

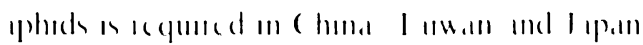

\section{Americas}

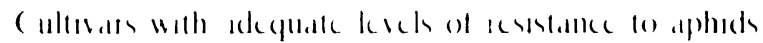

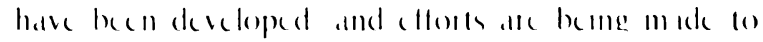

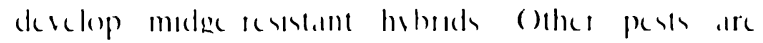

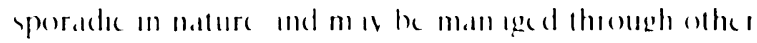
componcons of pest mallagement the pardsile

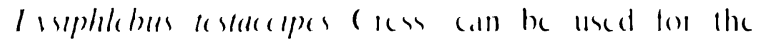
mallagement of apheds in compunctuon with rosstant balcles (Stanks Munlappan and I ihenban 1972 stanks Wood and Buiton 1974)

\section{Australıa}

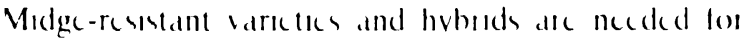
control of thes majer pest ()ther pests whele ale sporade in nature ma be contiolled through other components of IPM 


\section{Eastern Africa}

In Burund Fthopla Kensa Ruanda Somalıa sudan. Ianzanta and Jganda the serenits of $416 \mathrm{~m}$ borers, midge shoot fls and aphads deflem Aims. worms and locusts are sporade pests while head bugs mav become serous on lale-flowermg sopes In equatoral areas, tho successace crops of sorghum ale grown during the long- and short-sedson r.mIs in addition the soungs are staggered in relation to

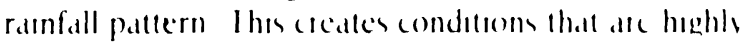
conducive to encreased populatuons of shoot the and madge I ocal landraces are tall photoperoud semsitase coloused (less damaged be birds) and hate specific adaptations for pests, diseases and drought depending upon altatude latitude and ramiall pallern Io mere ane sorghum productivity short-durdton (for dooughtprone areas) and medium-duration cultivars ate required Resistance (or at least some foletance) to stem boress and shoot fly is essential in most alleds especally the drier lowland and mal hill areas where most sorghum is grown Famers hale a marked preterence lor red sorghums to mommose hard damage but, where lagge alcas are sown, while sorghums can be cultivated fo increase crop productivilt and impiove nutrition Resstance to aphids sa also essential in some of these areas Resistance to mige will be most desirable for regions in which the sowings are staggesed or where the genotypes with different maturites ale grown, eg the lowlands of I thop)ta (Gambella ecgeon). the medlands of kenya (Bused regron) and I ansanid As resstance to shoot llices and modge is not avalable in the same bategrounds, genotypes with specific resistances to these pests may be sown ovet large areas to avord population build-up Mixcd cropping of sorghum with cowpeds together with biological contiol, can also be used to mummore the damage by stem boters (hemeal control is largely non-existent in these areas, but in epideme stuations such a majot armyworm infestations, chemical control may be necessary With a change in the croppeng patterns and the cultivars grown, the situation with head bugs (lavlorilyeus) may have to be valthed carcfully

\section{West Africa}

In sub-Saharan Africa (Mauritanid, Sencgal, Malı, Niger, Nigerla, (ameroon, Burkind Faso, I ogo, Ivory Codst, Ghand, ele ), the major pests of sorghum are head bugs, midge, stem borers and shoot tly Farmers usually grow tall photoperiod-sensilive gumene landraces, which flower at the end of the rany season during the last week of September In some areas, durra and durra-bicolor sorghums are also giown there is a wide varidtion in ranfall (40)(0) 15()$(0) \mathrm{mm})$ in the sorghum-growing areas, accordingly, landraces with specific adaptation to different agroclimatic regions are grown by the farmers Efforts to replace the local landraces have largely been unsuccessful because of problems of adaptation and food quality Ihe latter

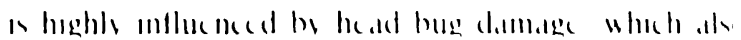

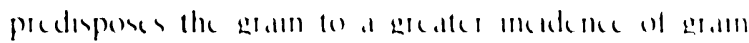

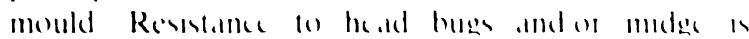

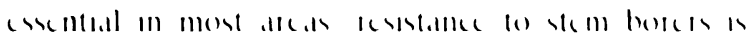

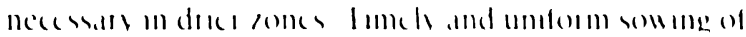

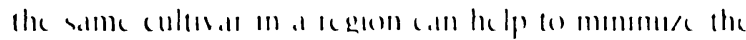

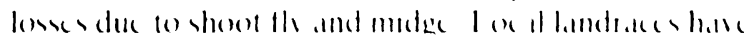

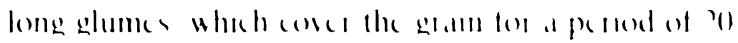

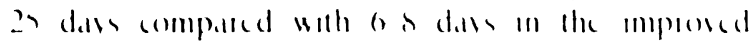

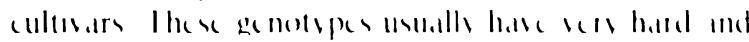

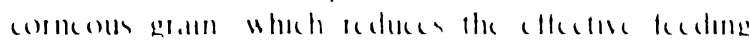

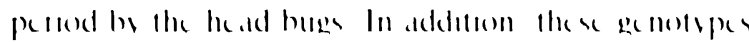

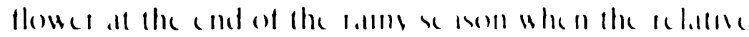

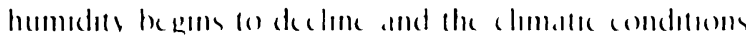

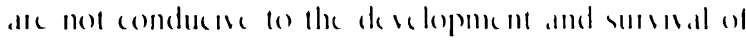
he.d bues

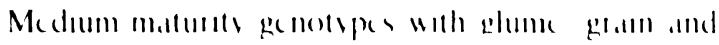

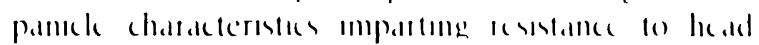

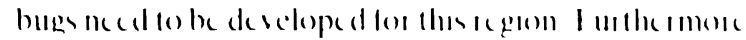

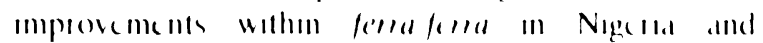
gurme'mse sorghums in othe regoms would be hehls

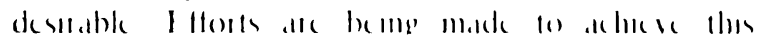
ohpective in I( RISAI s sorghum mperosement pro

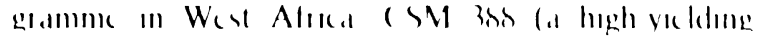

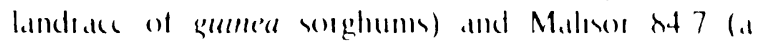

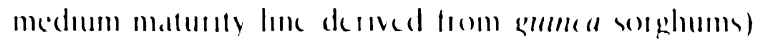

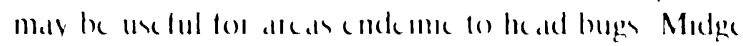
resistant lines mat be asclul in alleds where molge

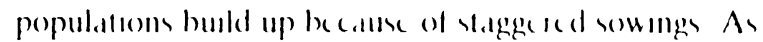
head bugs are extermal kedes chemeal conteal is fanly cllective and a sugke applicallon of a readils

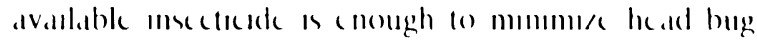
damage lotceroppeng sorghum wilh cowpeas (which is the most important legume (Iop of the 1 (e geon) (ant also) be used to reduce the damage by stem horess

\section{Southern Africa}

stem boress, shoot lly amoured erechel and aphids are some of the important pests of sorghum in southem Alaca Head hugs have begun lo appeal on newly developed genotypes in Botswand Both loxal landraces and improved genotypes are grown by farmers in the regenen (ultevars with resstance lo borces and aphade may be applacable to the integrated a st management systems limely and uniform sowing can reduce the incidence of shoot fly and midge, and adeyuate fertulizer application can help to reduce damage by borers Head bugs may have to be watched catefully on newly developed cultivars Bards are by far the most important pests in thes regeon (oloured grann soighums with a high tanmon content, which ale also useful in the brewing industry, may be developed for these areas

\section{Notes and acknowledgements}

Ihe author is gratcful to Dr G A Matthews, UK, for his encouragement to prepare this manuscript, to Drs J $M$ J de Wet, K F Nwanze, A M lein Fl-Abdin 
and R I Saltrandrat,and Ralo for the 1 comments lo

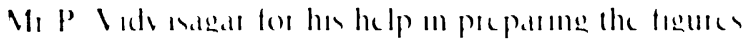
D) $>$ I lanefa for prouding some dalla on show th and stem hore and Mi I Kashnd Murthe for erpme the manuscupt

Approucd a JA No 1269 by IC RISA I

\section{References}

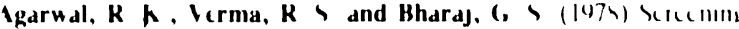

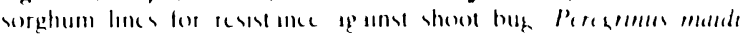

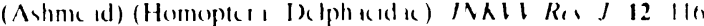

Igrawal, B I and Abraham, ( I (1945) Brecdinf sorphum for

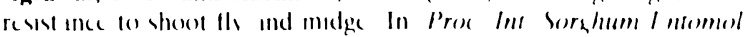

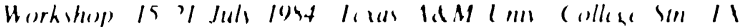

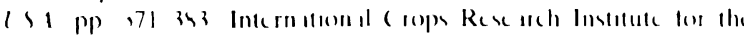

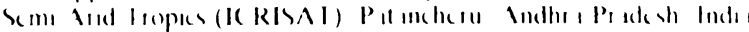

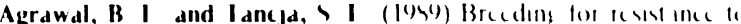

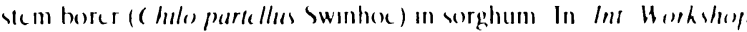

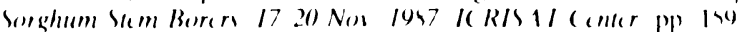

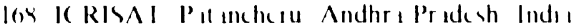

Agrawal, $B$ I. Abraham, $(I$ and House, I $R$ (l945) Inhe rll

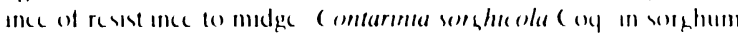

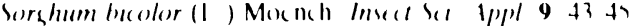

Agrawal, B I , Sharma, H I and I cusehner, K (19487) Re! M11

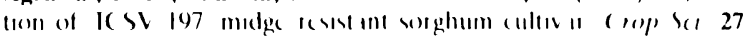
13121313

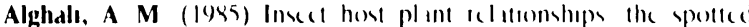

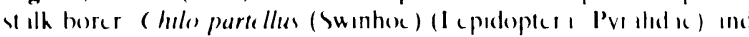

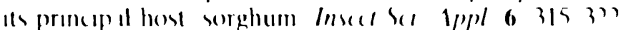

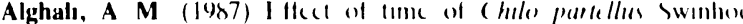

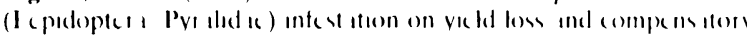

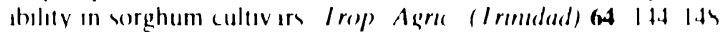

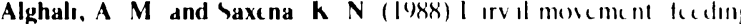

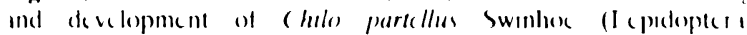
Pvralidu) on two sorghum cultivirs Inseat ba Appl 9711

Archer, I I , Bynum, I D and Peterson, (, ( (I9)6(1) Impont ince of plant senescence on grin sorghum resst ince to the Bumb for milc (Acarl Ictranychidu) J $/$ (on) $/$ ntomol 791517

Balakotalah, K, Kana, B S, I ripathı, I) P and Kao, N (, P

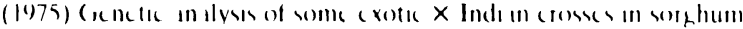
$x$ Inheritance of resist ince lo sorghum shoot tly lndian $J$ (nchel 35344349

Balasubramanian, (, , Sivaprakasam, K, Kulandavelu, $K$ and Robinson, J (, (1979) Impact of sorghum carhe ads on the incide nee of e arhe adbug c itcrpill ar webber and mould Indean I lara Ras $1310610 x$

Baletkd, A D and (astellano, S $R$ 11984) I c vels of grcentur (Schizaphus grammum (Rond )) resist ince in cultiv ars of commercai grun sorghum sorghum N(n)lell $27 \times 1$

Bapat, D $\mathbf{R}$ and Mote, U $\mathbf{N}(1982$ a) Uperading the resst ince kul

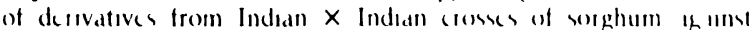
shootfly J Maharashtra Agru U/nu $7 \quad 171-173$

Bapat, I) $\mathbf{R}$ and Mote, $($ N (1982b) Sources of shoot fly resst ince in sorghum J Maharashira Agra Umn $723 \times 24(1$

Bergquist, $\mathbf{R} \mathbf{R}$, Kotar, P and Mitchell, W ( (197.4) Midgc inc anthracnose head blight resstance in sorghum Trop Agris (Trinidad) $51+431-435$

Bernays, F A, ( hapman, $R$ F and Woodhead, S (1983) Bch w1ou of newly hatched larvac of ( hilo partelles (Swinhoc) (I cpidopter I Pyralidac) associalce with their cslablishment in the host plant sorghum Bull I ntomol Res 73 75-83

Biradar, S (, and Borkar, S I (1985) ( enclk alldlysis of shoot fl. rcsistance in relation to growth stagcs in sorghum / Pfl/uchl 95 $173-178$

Blum, A (1968) Anatomical phenomend in secdlings of sorghum varictics reststant to the sorghum shoot fly (Atherigona iaria soc cata) (rop S(t 8 388-39)

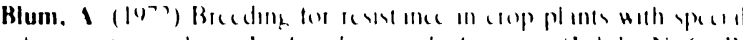

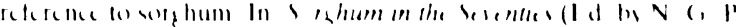

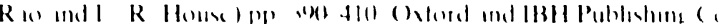
Vis l) (h) Ind

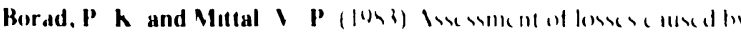

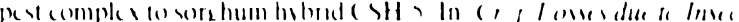

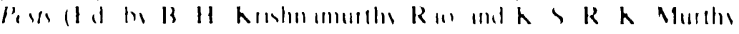

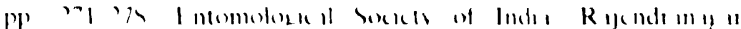

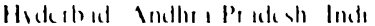

B(x)/ara- Ing(x)n b Starks $h$ J Habel I) I and Iextes (, I

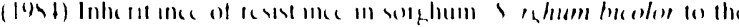

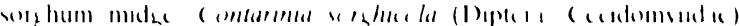

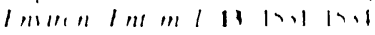

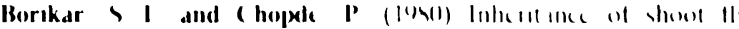

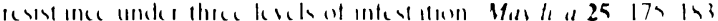

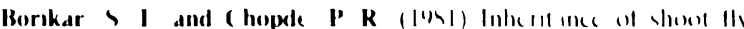

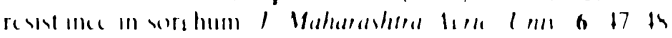

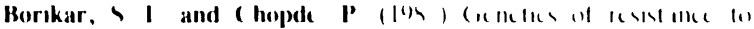
(1)

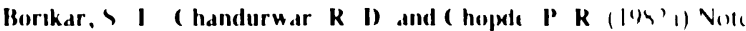

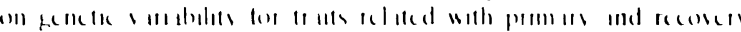

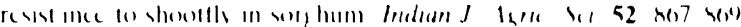

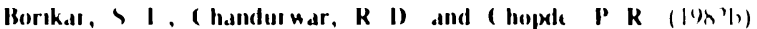

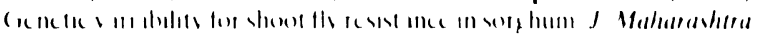
lall 1 mII 7 W?

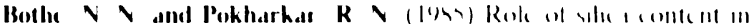

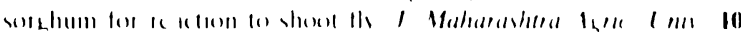
334339

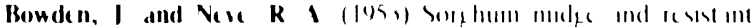

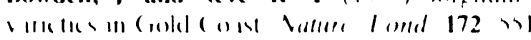

Burton K ( Burd I I) Jones () $\mathrm{K}$ and Wiaks (, A (1\%)(1)

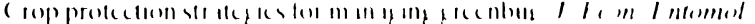
$83,176,179$

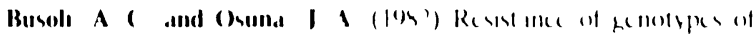

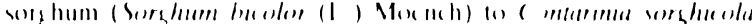

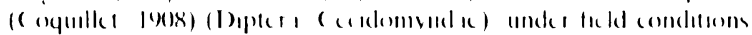

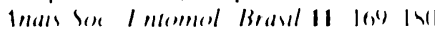

(amplell, B ( Vilean, I) I Kinser M (, Jones $K$ ( and

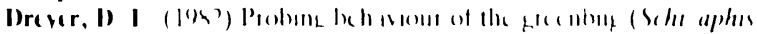

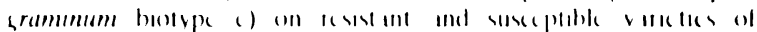

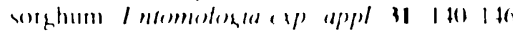

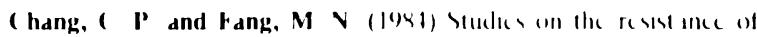

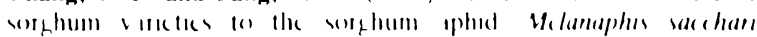

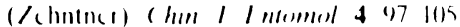

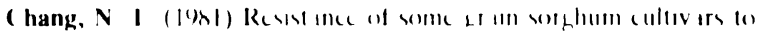

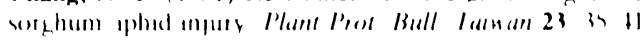

(hapman, $\mathrm{K}$ I Woxdhead, S and Bernavs $\mathrm{A}$ (I)k3) Sumbiv

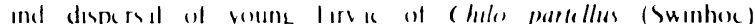

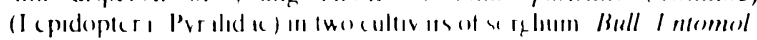
Rr, 736571

( rus. I and Vendramen, I I) (I9)hs) I flecte of different le vels of

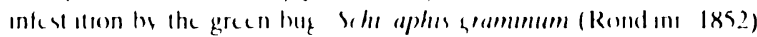

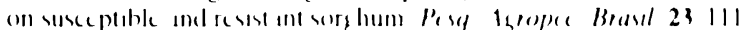
IIX

Dabrowski, I I and Kidiaval, I I (1983) Resstalles of some

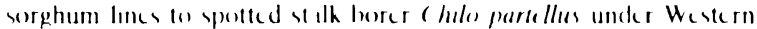
Kenviconditoms Inset to 1ppl 4 119 126

Dalvi, (, , Daldya, V P and Khanvilkar, V (, (I983) Sercemng

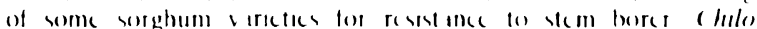
partellus (Swinhox) Indian J I neomol 45 26x- 77

Dalvi, ( T, Daldya, V P and Khanvilkar, V (, (I)O(I)) Screcning of some sorghum vircules for resset ince to shoot lly Alheresona soccata Rond ans Indian J I ntomol $52 \quad 279$ 280

Davies, J ( (1981) lest losses and control of d im sge on sorghum in devclopeng countres the re thites and mvth, In Sorghem in the

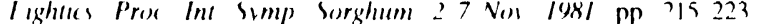
IC RISAI Patancheru Andhri Pridesh Indas

De Pew, I J and Witt, M I) (1979) I valuations of grcenbug resstant sorghum hyhisds $I$ I am I ntomol $72 \quad 177 \quad 179$ 


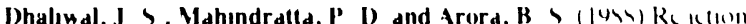

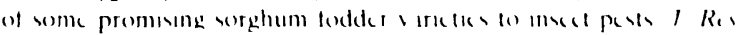

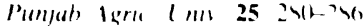

Dixon. A (, (). Brand ( ox, I) I. Reese. J ( and Harics. I I

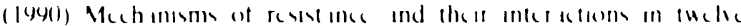

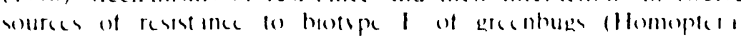

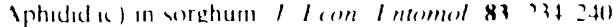

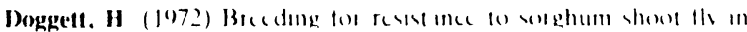

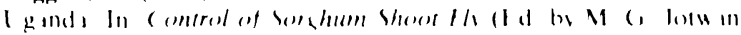

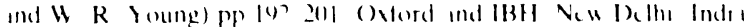

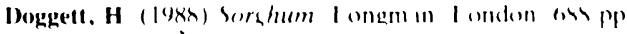

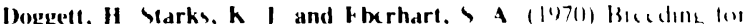

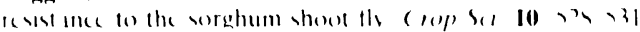

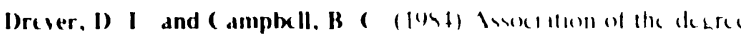

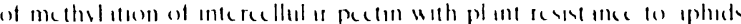

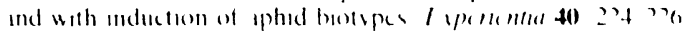

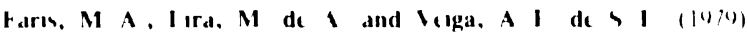

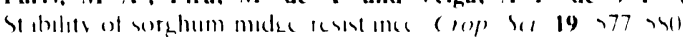

Ioster, I) (, Icetes, (, I Johnson, I W and Ward, 1 R (19) )

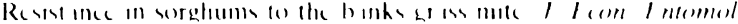
70) '(1) '?

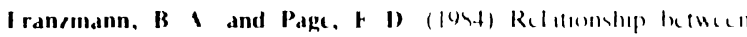

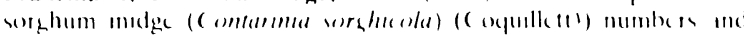

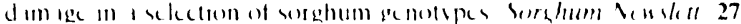

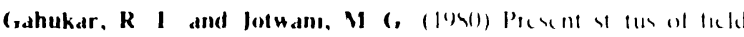

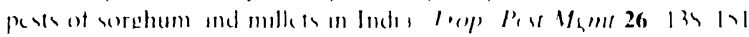

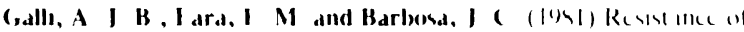

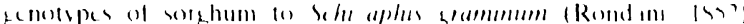

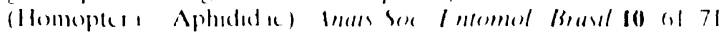

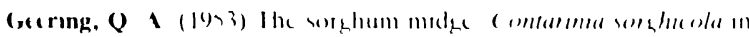

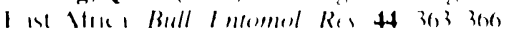

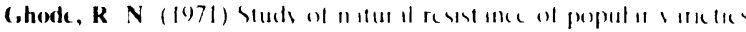

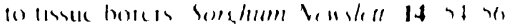

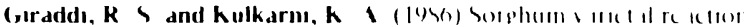

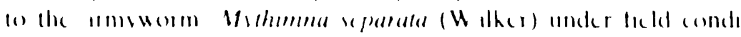

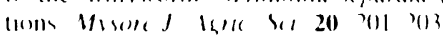

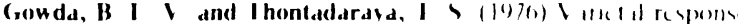

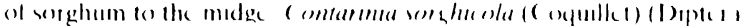
(codomunde) (111) ) 4177 174)

couragosslan, I and Mihm, I I (194) Improsule host plint

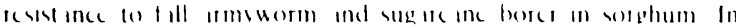

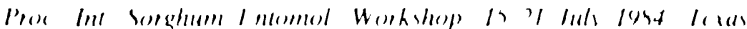

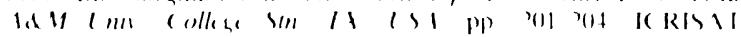

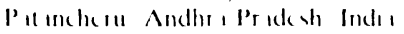

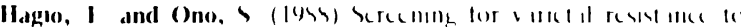

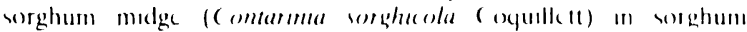

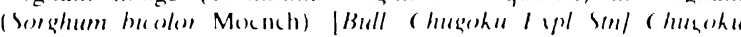
Doguo Shahenjo hellhia Hohohu 2 I 11

Hagio, I, I mehard, $M$ and Ono, $\rightarrow(19 \times 5)$ V arketil k ktkin of sorghum to sugercalle iphel (Melanaphes sachars/chntnet) in the secdling stage forghum Nenslett 28 if 52

Hagio, I, Hoshono, I, Ono, S and I mehara, 11 (19ht) V mkl

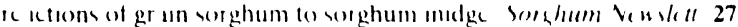
(1)

Hallman, (, J, Teetes, (, I and Johnson, I W (19h4) Rclitum she of sorghum matge (I)ipter a (codomvidac) de nutty to damage in restatat and susceptable sorghum hybrids $J$ I om 1 ntomol 77 8387

Hannd, W W, Wiseman, B $R$, Duncan, $R \mathbf{R}$ and schert, $K \mathbf{F}$ (1989) Regestration of Iift MR \&x midge resstant sorghum germ plasm (rop sel 29246248

Harver, I I and Hackerott, H I (1974) I ffects of greenbugs on icsist int ind susccptible sorghum secdlings in the ficld $J /$ om I ntomol $67 \quad 377 \quad 380$

Harves, T I and Thompson, $A$ (198x) Lffects of sorghum densits and esistance an infestation of grcenbug Schiaphes gramunum (Homopter Aphididac) J hansas / ntomol soc 61 hx-71

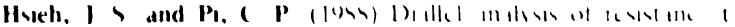

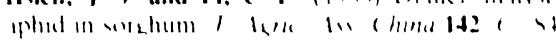

IC RIS II IInternational ( rops kesearch Institule for the seme Trie

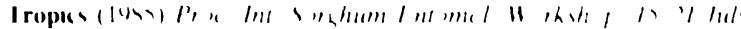

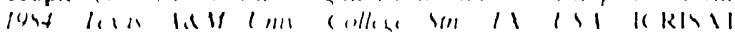

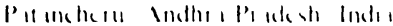

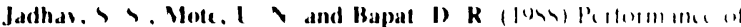

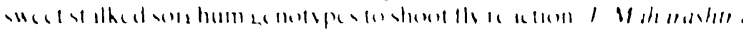
lall $1 \mathrm{mil}$ is ?, ?

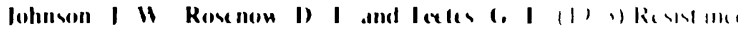

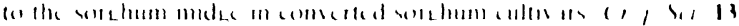
Tht

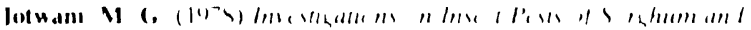

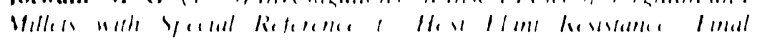

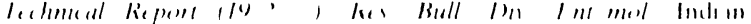

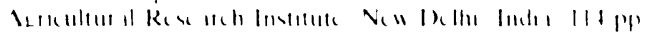

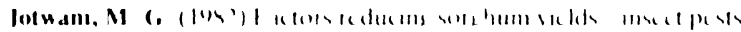

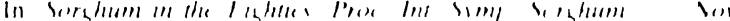

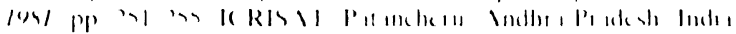

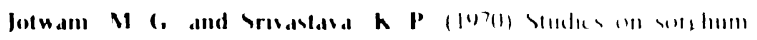

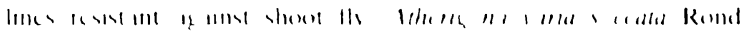
Incluan | 1 mammal 321 ;

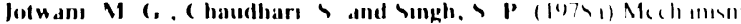

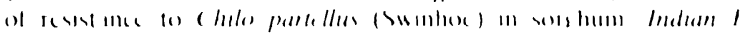

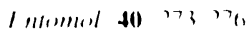

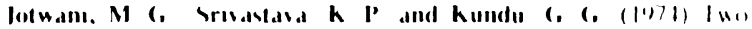

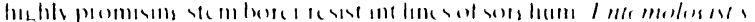
$1,11 / 11+11)$

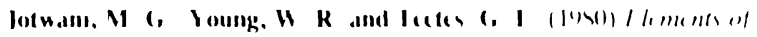

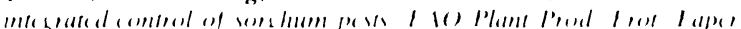
I (1) Rome lis I"

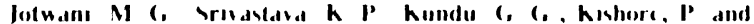

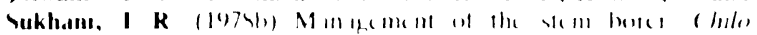

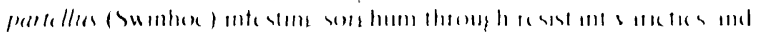

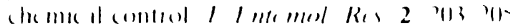

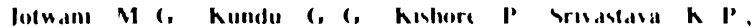

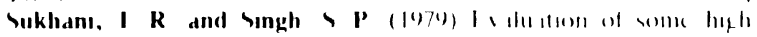

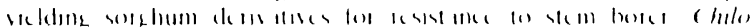

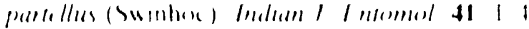

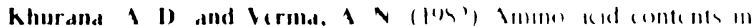

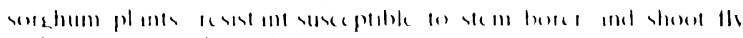
Indean I Intomenl it int in

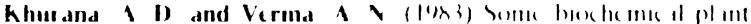

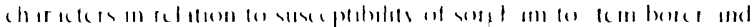

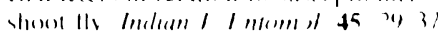

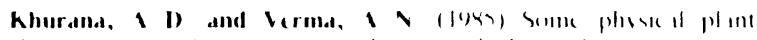

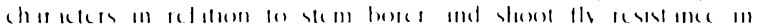

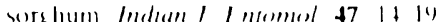

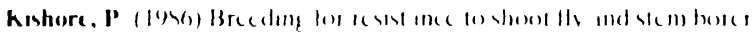

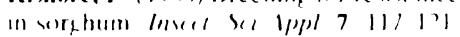

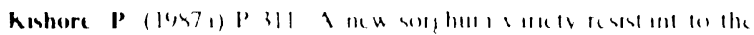

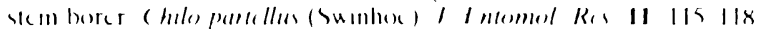

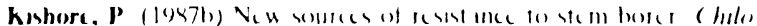

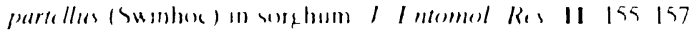

Kishore, I', Jotuam, M (, and bharma, (, ( (1977) berecming of

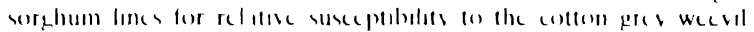

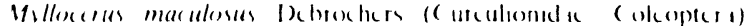
Incluan 1 / ntomol $393793 \times 1$

Kashore, P. Kana, Bs s and Agarwal, $\mathbf{k}$ (1985) belection for

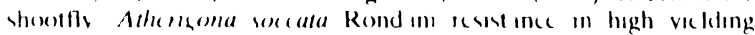
bicklks of sorghum $1 / \mathrm{momol}$ Res 9 18x 19.4

Kishore, P', Kand, B S and Sharma, (, ( (1984) belcctoon for stem borer (helo partellus (Swinhox) resst ince in segregating gener lions of orghum J 1 ntomol Res 82124

Krishnananda, M, Javaraj, S and Subramaniam, I R (1971) Resistance in sorghum to stem fly Athorigona iaria soccata $R$ Madras Agric J $57 \quad 6746,79$

Kulkarni, $K$ A and Ramakrishna, V ( (1975) Studse on the 


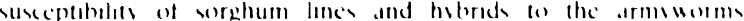

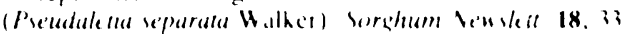

Kulkarni, K. A.. Parameshuarappa, R. and Kajjari, V. B. $(19-3,1)$

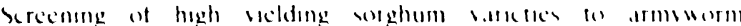

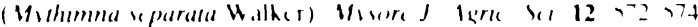

Kulkarni, K. A., Parameshuarappa, R. and hajjari, V. B. (1673h)

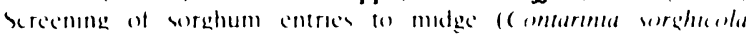
(cquallett) busere l lerk la $1257^{\circ}, 75$

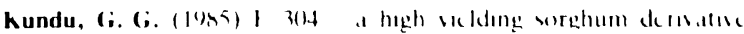

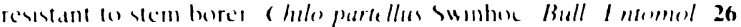
2527

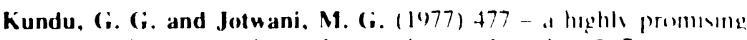

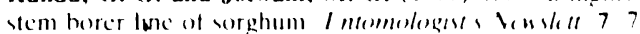

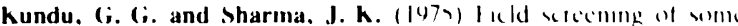

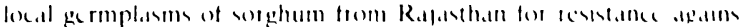

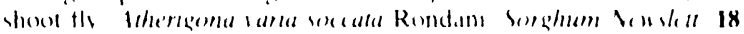
5x 5y

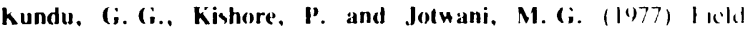

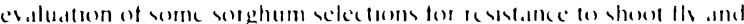

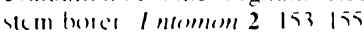

Iakshminarayana, h. and subba Kao, D. I. (1979) serecmeng of

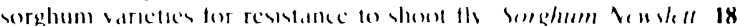
$22-23$

I.al, (;. and Pant, J. (.$(198(1)$ ()

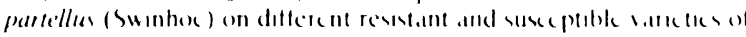

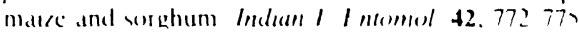

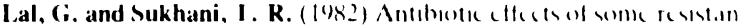
lines of sotghum on pest lats.l derelopment of (hele parlellas

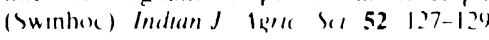

I.ara, F. M., (ialli, A. J. B. and Busoli, 1. ('. (|9h|) $|y| x)$ (1)

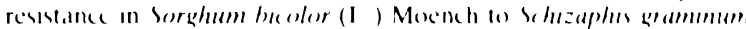

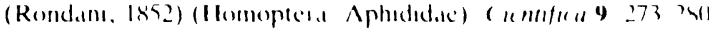

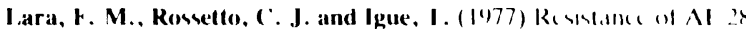

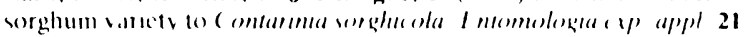
238212

Lara, F. M. Barbara, F. C. C ., Busoli, A. C. and Barbosa, I. C.

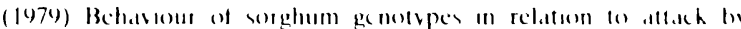

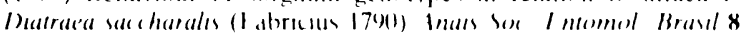
125130

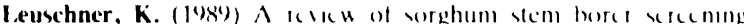

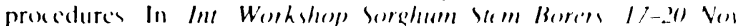

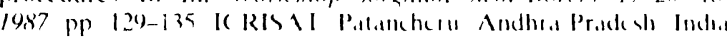

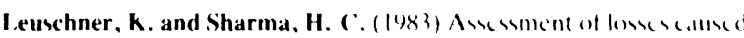

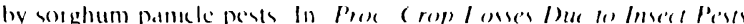

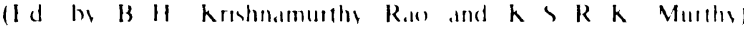

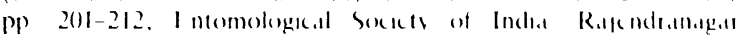
Hyderabad, Andhta Pradesh. Indta

Ieuschner, K., I aneja, S. I.. and Sharma, II. ( . (I9h)) I he role "1) host-plant resestance in pest management in sorphum in Indas Inser S(1 1 , ppl 6 o $153-4(0)$

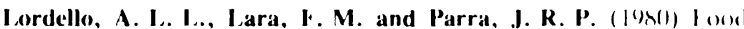

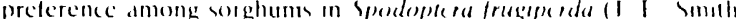
1797) (I eprdopter. Noctudda) under l.1botalors condeloms leas soc 1 memol Brasl 9. 219-2+1

Maiti, K. K. and Bidinger, H. R. (f1979) A smple apptostch w identification of shoot flv toledance in sorphum Indaun / Plant Prot 7. $135-140$

Maiti, K. K., Bidinger, F. R., Seshu Reddy, K. V.. (iibson, I'. and

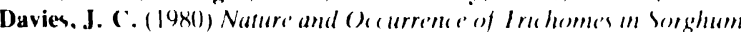

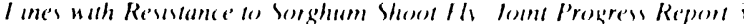
of Sorghum Phowlogi and Sorghum I ntomologe. IC RISA I Paldacheru, Andhra Pradesh. India (limited destribution)

Mate, S. N., Phadanwis, B. A. and Mehetre, S. S. (198x) Studies on growth and physological tactors in reldtion to shoot fliv attack on sorghum Indian J Agric Res 22, $81-84$

Melton, K. D. and Teetes, (i. I.. (I984) Effect of resistant sorghum hybrids on sorghum modge (Dipterd (ceidomvindac) bologgy $J$ licon Entomol 77, 626-63)

Mihm, J. A. (1985) Methods of artificial infestation with Daatraea

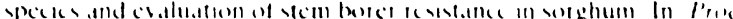

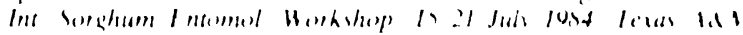

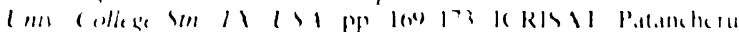
Indha.a liaksh Indi.

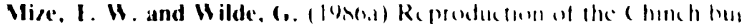

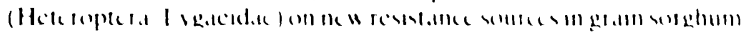

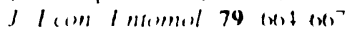

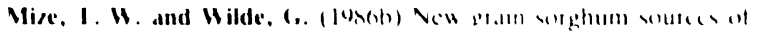

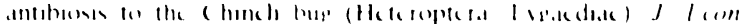

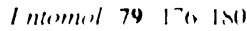

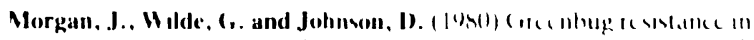

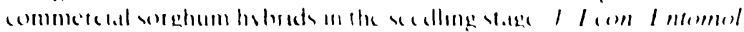
73. 5111,11

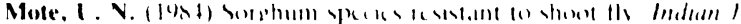
I ntomel th $211 ?+3$

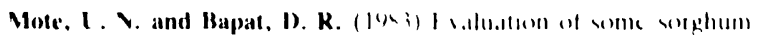

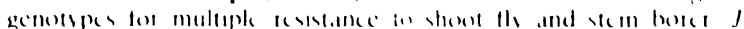

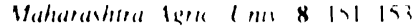

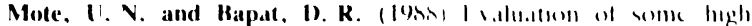

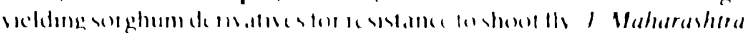

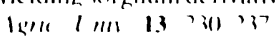

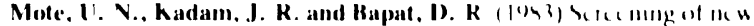

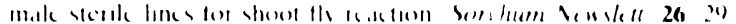

Mote. (1. V., Kadam, J. R. and Bapat, I K. (19h) Recosers

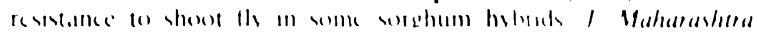

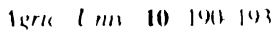

Mote. (1. N., Kadam, J. K. and Bapal, D. R. (19ha) Antubuss

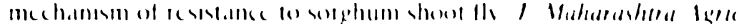
l'mil 1113 16

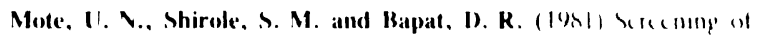

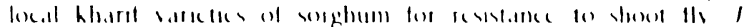

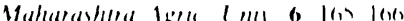

Murts, A. I). and Subramamam, I. R. (1979) \.111 (.1) suscephlulals

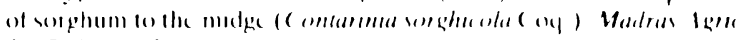
$65|x| 1 \mid$ is

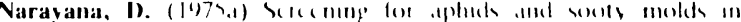
(1)

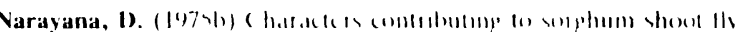

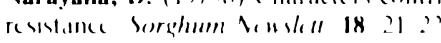

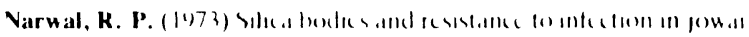

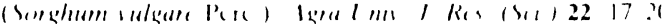

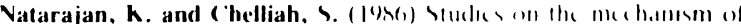

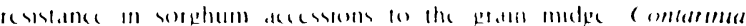

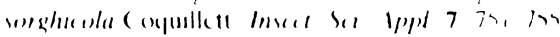

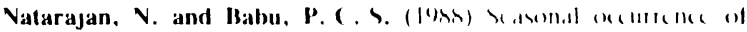

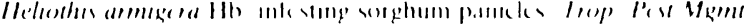
343 is $31 ?$

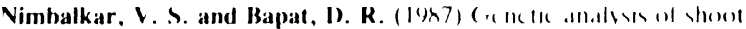

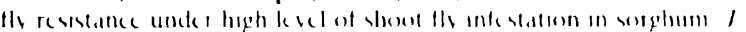
Maharashera 14:"le l'mll $12 \quad 331 \quad 331$

Vordquist, P. I., Kindler, S. I). and Spemer, S. M. (1987) Repustr.

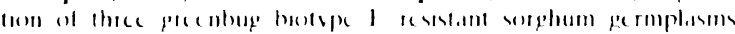
( roli) $1127 \quad 151$

Vwange, K. F., Reddy, Y. V. K. and Soman, P. (|99(1) lhe tele of

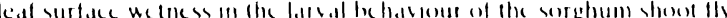

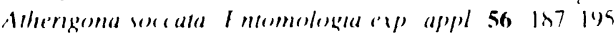

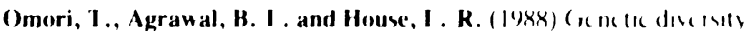

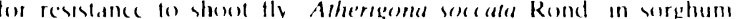

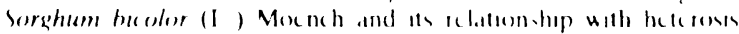

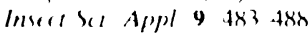

Page, F. D. (1979) Resestanes to sorghum molge (6 amtamame

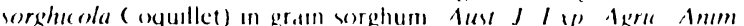
Hush 19,97-1111

Parodi, K. A., (iamba, R. I). and Scantamburlo, J. I. (1'174) - Hueron INIA gran worghum varkelv tolerant io the sorghum

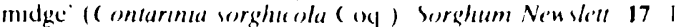

Passlow, T., Franzmann, B. A. and Allsopp, P. (;. (1985) Sorghum insed problems in Australia In Pros Int Sore/hum I ntomol 


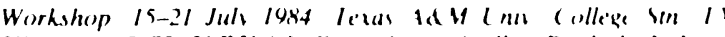
USA pp 65 72 IC RISA I. Patancheru Andhra Pradesh Indid

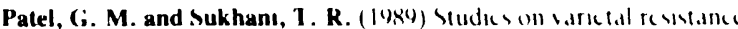
(1) sorghum stem borer (halo parkllas (Swinhou) Indan J I ntomol $5138+34$ ?

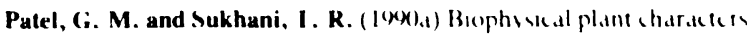
assoclated with shoot flis resstance Indian J I ntemel 521417

Patel, (;. M. and Sukhanı, I. R. (IF)(h) scremeng of sorghum genotvpes for resstance to shoot fls theregona wecata Rondans Indian $J$ I ntomol 52 i $\lambda$

Patel, G. M., Sukhani, I. R. and Srivastava, K. P (1984) Studic on multiple resplance in sorghum to shoot th and stem borers Indean J Intomol 51, 26) 260

Patel, R. H., Desai, K. B., Desal, M. S. and Kukadia, M. U. (19)(6) (ombining ability for resstance to carbed worms in sorghum (rujarat Agric (Imu Res J II 79-81

Pathak, R. S. (1985) (éncte barlation of stem boret resstance and tolerance in three sorghum crosses Imeet bet $A p p l$ o 35936.4

Pathak, R. S. and Olela, J. C. $(1963)$ (enctics of host plattl resistance in food crops with specidl reference to sorghum stem borers Insect Sa Appl 412713.4

Patil, R. C. and Thombre, M. V. (1985) Inheritance of shoot fls and carhedd midge fly resstance in sorghum ( urr Re's Reptr Mahatmo Phule Agric l/nu 14448

Perring, T. M., Archer, T. I.., Johnson, J. W. and Phillips, J. M. (1982) Fvaluation of several grall sorghum characteristus for resistance to) Banks grass mite $J$ I con I ntomol 75 257-26x)

Peterson, G. ('., Johnson, J. W., ' ertm, (. I. and Kosenow, D. I. (1985d) Registration of midge resistant sorghum germplasm ( $\mathrm{rop}$ ) il 25, 372

Peterson, G. C.., Johnson, J. W., Teetes, (. I . and Kosenow, I). I (1985h) Registration of grecnbug biotvpe ( resistant sorghum germplasm ( rop St, 25, 373

Peterson, G. C., Ali, A. H.. B., Teetes, G. I.., Jones, J. W. and Schaefer, K. (I989) (iran sorghum resstance to sorghum madge by yield loss vs visud seores ( rop ba 29, $1136-11$ 10)

Ponnaiya, B. W. X. (1951) Studes on the genus Sorghum II Ihe cause of resistance in sorghum to the insect pest Atherigona indea $\mathrm{M}$ Madras Unu J (B) 21, 201-217

Pradhan, S. (1971) Investugations on Inse'ct Pest of Sorghum and Mille's Final lechnical Report (1965-70) Induan Agricultural Rescarch Institute. Division of Fntomology New Delhi Indid 157 pp

Raina, A. K., Thindwa, H. Z., Othieno, S. M. and ('orkhill, R. I . (1981) Resstance in sorghum to the sorghum shoot fly larval development and adult longevity and fecundity on selected cultivirs Insect sa Appl 2,99 1113

Kaina, A. K., Thindwa, H. Z., (Othieno, S. M. and Bouglass, L. W. (1984) Reststance in sorghum to shoot fly (1)iptera Muscidac oviposition on selected cultivars J I con I ntomol 77 648-65I

Rana, B. S. and Murty, B. R. (1971) (enetle andlysis of reststance to stem borer in sorghum Indian J Genet 35, 350 355

Rana, B. S., Jotwani, M. G. and Rao, N. (;. P. (1981) Inheritance of host plant resstance to shoot fly in sorghum Insect sa Appl 2 I(15$1(k)$

Rana, B. S., Tripathi, D. P., Balakotaiah, K., Damoder, R. and Rao, N. (j. P. (1975) Genctic analysis of some exotic $\times$ Indian crossces in sorghum IX Selection for shoot fly resistane Indian J Genet Plam Breed 35. 350)-355

Rana, B. S., Singh, B. U., Rao, V. J. M., Reddy, B. B. and Rao N. (i. P. (1984) Inheritance of stem borer resistance in sorghum Indtan J Genet Plant Breed 44, 7-14

Rangarajan, A., Mahadevan, N. R., Kandaswamy, (j. and Iyemperumal, S. (1974) Some observations on the susceptibility of sorghum types and hybrids to the cut worm. Pseudaletia unipuncta Haw Sorghum Newslett 17.48

Rao, N., Singdi, S. S. and Srinivasulu, (;. (1972) Brecding for shoot fly resstance in sorghum Sorghum Newslett 13, 32-38
Rao, \, (, P . Rana. B \, Balakotalah, K., I ripatho, I) P and

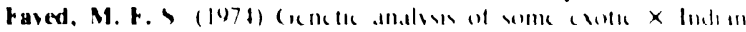

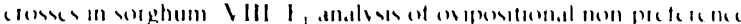

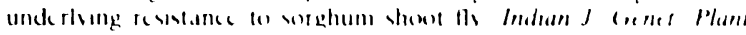
Breed .4 12:127

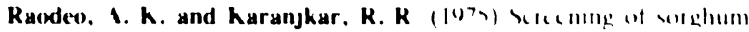

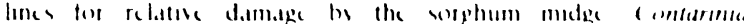

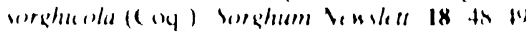

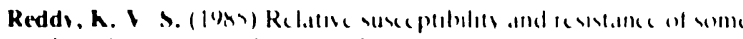

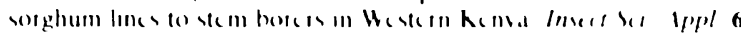
Hi) $1(4$

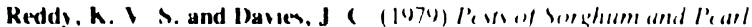

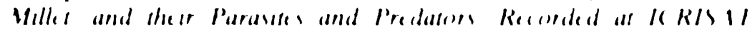

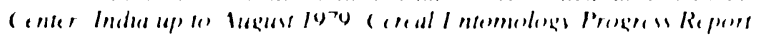

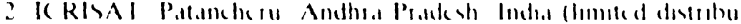
(10)1)

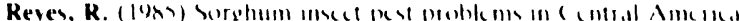

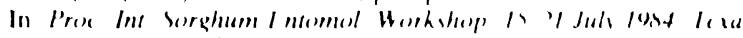

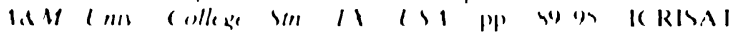
Patamehoru Andhra Pradesh Indiat

Ross, W M., kindler, ( I), hofoid, $h$ I), Henokstra, (, II

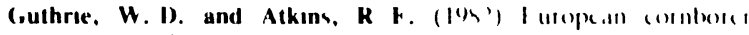

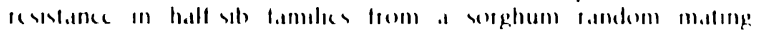

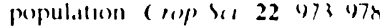

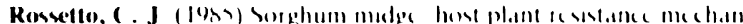

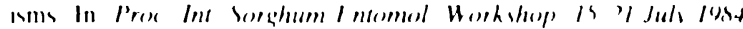

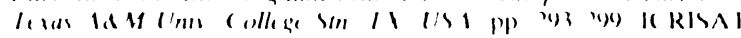

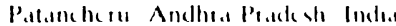

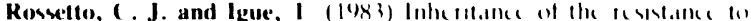

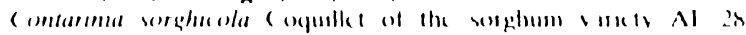
Bragantia 42 ?II? ?9

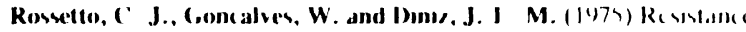

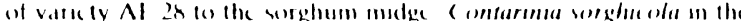

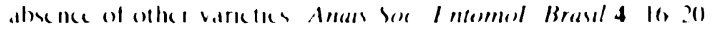

Rosselto, ( . J., Nagal, V. and (Dverman, J (1984) Mech.1musm of

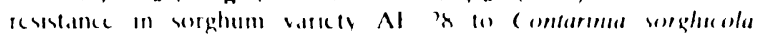

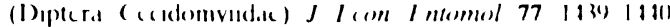

Salunkhe, (, N., (,andhale, D). N., Murts, I h and Naik, I . M.

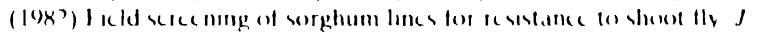
Maharashera Agru l/nu 7270

Sandhu, (., S., Whaliwal, (;. S. and Sidhu, B. S. (19)66) R(smst.mec of forage sorghum to shoot fly (Atheregena socata Rond ) Indian J Apric Sa 56753750

Santos, J. H. R. and Carmo, ('. M. (1974) I valuation of resstance (1) Contarina sorghicola by sorghum lines from ( amcroon Alrica collection) in ( eadra Brasl Sorghum Nenste'l 17, 10t I1

Schuster, D. J. and Starks, K. J. (1973) (, recentsugs componc nts of host plant tessstance in sorghum $J$ com $I$ ntomol o6 11311134 schweissing, F. ( . and Wilde, (;. (1978) I mperature influence on greenbug resstance of crops in the secdling slage 1 nutron 1 ntomol $7 \times 31 \times 37$

Shweissing, F. C. and Wilde, (i. (1979) I emperature and plant nutrient cffects on resstance of seedling sorghum to the grcenbug $J$ I con I ntomol 72, 2023

Segarra-Carmona, A. L., Sotomayer-Rios, A., Torres-Cardona, S. and Quiles-Belen, A. (1989) I ield evaluation of the susceptibility of eight sorghum hybrids to the sorghum midge, ( ontarinia iorghie ola (Coquillet) (Dipterd Cecidomyindac) J Agric Una Puerto Rico) 73, $155-157$

Sharma, (;. C. and Kana, B. S. (1983) Resistance to the sorghum shoot fly Atherigona soccata (Rond) and selection for antibiosis $J$ I ntomol Res 7, 133-138

Sharma, (;. C. and Rana, B. S. (1985) Genetics of ovipositional nonpreference and deadheart formation governing shoot fly resstance in sorghum $J$ Entomol Res 9, I14-1115

Sharma, G. C., Jotwani, M. G., Rana, B. S. and Rao, N. (i. P. (1977) Resistance to the sorghum shoot ny, Atherigona soccata (Rondani) and its genetic analysis $J$ Intomol Res 1, 1-12

Sharma, H. C. (1985d) Strategies for pest control in sorghum in India Trop Pest Mgmt 31, 167-185 
Sharma, H. C. (1985h) Screcning for sorghum midge reststance and resstance mechanisms In Pros Int Sorghum Fntomol Worhihop. I5-2I Juls 1984. (ollege Sin. IA, ISA, PP 275 242. IC RISAI, Patancheru. Andhra Pradesh. Indad

Sharma, H. C. (1985e) Sereeneng for host-plant resistance to murid bugs in sorghum In Proc Int Sorghum I ntomol Worhshop, Is 2I Juh 1984. (ollege sin. IS, I'SA, pp 317 335. IC'RISAI. Patancheru. Andhra Pradesh, Indid

Sharma, H. ('. and Davies, J. C. (1983) Ihe (Mriental Trminorm, Mvthimnd separdta (W/h) Destribution. Biologes and (ontrol a

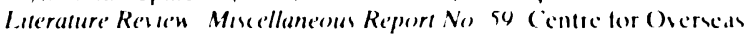
Pest Rescarch, I ondon, 24 Pl)

Sharma, H. $1^{2}$. and Davies, J. C. (1988) Insert and ()ther Inmul Pe'sls of Mille's Sorghum and Millets Informatton ('enter, IC'RISA I Patancheru. Andhra l'radesh. Indial

Sharma, H. (C. and L euschner, K. (1986) Mechanmms and diversitt of resstance to the sorghum midge. (ontarma sorghteola ('og In

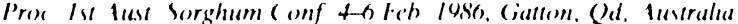
PP $3 \times 319$. ()rganising (ommitlec of the Austialian Sorghum Conterence, (ialton, Oucemsland, Australid

Sharma, H. C. and Ieuschner. K. (1987) ( hemedl control of sorghum head hugs (Hempteris Miridac) ( rop Prot 6, 34340

Sharma, H. ('. and Iopes, V. F. (I989) Assesment of avoudable losses and coonome injury levels for the sorghum head bug. (alocors angustatus I eth (Ilemiptera Miridac) in Indas (rop) Prot 8. $429-135$

Sharma, H. ( . and Lopes, V. F. (199(1) Mech.1mums of resstance in sorghum to head bug. (alocors angustatus I ntomolosala exp appl 57. 285294

Sharma, H. C. and I,opes, V. F. (|99)|) Stability of resstance to sorghum hedd hug. (alocors angustams I ethery (Hemptesd Miridac) I $I$ (om I ntomol 84, I(1)88 I(k)4

Sharma, H. C. and lopes, V. F. (1992.1) Screcong for plant resstance to sotghum head bug. (alocors angustatus I cth Imset Sa Appl 13. 315325

Sharma, H. C. and I,opes, V. H. (1992h) (enotype resstance in

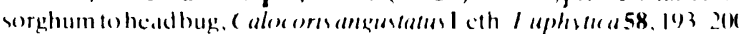
Sharma, H. ('., Doumbia, Y. (). and IDiorisho, N. Y. (199?.1) Screcming sorghums for resstance 10 hedd hug. I urusters

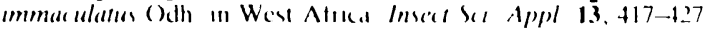

Sharma, H. ('., Ieuschner, K. and Vidyasagar, P. $(\mid(4)(), 1)$ I actor influcencing oviposition behaviour of the sorghum midge, (omtarince sorghucola Ann , 1ppl Basl 116.431 +30)

Sharma, H. C., Vidyasagar, P. and I.euschner, K. (|988d) I icld screcontng sorghum for resstance fo sorghum molge (f ecidomvadac Diptera) J I con I ntomol 81. 327334

Sharma, H. ('., Vidyasagar, I'. and leuschner, K. (1988h) No chonc eage techntque to screen for resstance to sorghum motge (Cecodomyindac Dipterd) J l.con I ntomol 81. 115-422

Sharma, H. ('., Vidyasagar, P. and Ieleschner, K. (199(1)) ('om ponents of resstance to the sorghum modge, (omarinas sorghicola Alnn Appl Bul 116, 327-333

Sharma, II. C., Taneja, S. I.., Ieuschner, K. and Nwance, K. I. (1992b) Te'hnegues to Screen Sorghums for Resstame' to Insects Info Bull 32, IC RISAT, Patancheru. Andhra Pradesh, Inda., is pl

Sharma, H. (., Doumbia, Y. ()., Haidra, M., Scheuring, J. F. Ramaiah, K. V. and Beninati. N. F. (194)3) Sources and mechanisms of resstance a) sorghum head bug. Furstrlus immas ulatus () $\mathrm{dh}$ in West Atrica Inseet Sat Appl, in press

Shivankar, V. J., Ram, S. and (iupta, M. P. (I989) I olerance in some sorghum germplasm to shoot fly (Athertgona socata Rondani) Ind $J$ I.ntomol 51, 393-396

Shivankar, V. J., Ram, S. and Gupta, M. P. (1989) Iolerance in some sorghum germplasm to shoot fly (Atherigona soce ata Rondanı) Indian J Entomol 51. 393396

Shyamsunder, J., Parameshwarappa, R., Nagaraja, H. K. and Kajjari, N. B. (1975) A new genotype in sorghum resistant to sorghum midge (Contarima sorghicola) Sorghum Ne's'stett 18, 3.3

Singh, B. U. (1987) Varictal resstance in sorghum to midge.

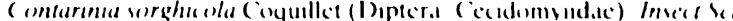
ippl 8. 124 14t

Singh. B. I'. and Kana, B. S. (198.t) Influchec of varietal reststance

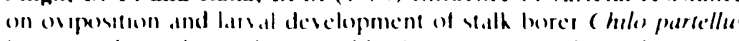

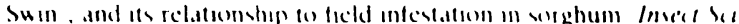
lppl 5. 287240

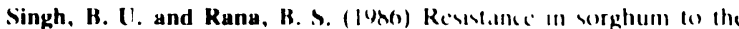

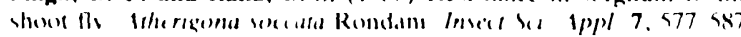

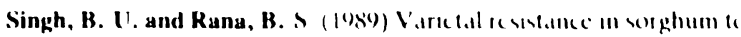
spotted stem bore ( hele partellus (Swinhore) Insed Sa Appl 10 327

Singh, B. I'. Rana, B. S. and Rao, N. (., P. (|9S'|) Hout plant

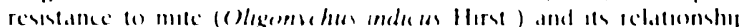

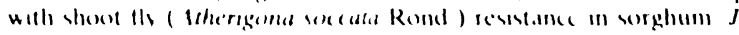
I ntomol Ros 5. 2) 30

Singh, B. (., Rana, B. S.. Keddy, B. B. and Rao, N. (i. P. (|983)

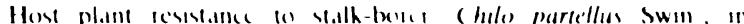
solghum Insed bet 1 ppl $4+10741$

Singh, K. and Naray ana, K. I . (1978) lufluc nec of different vallefle

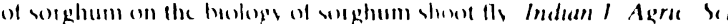
48, $\times 12$

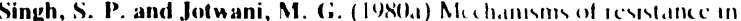

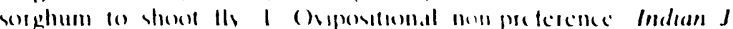
1 ntomol 42, 241t 247

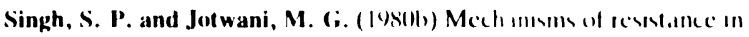
sorghum to shoot fly II Antihusus Indian J Intomol 42. 117

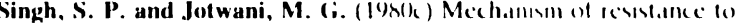

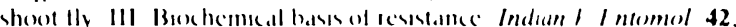
551596

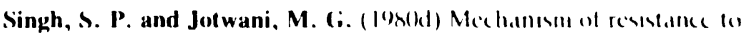

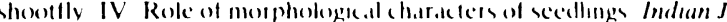
I noomol 42, 806808

Singh, S. P. and Verma, A. N. (I)hx, ) lubertance of resstance to

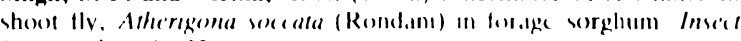
Sa Apl 9, 19-52

Singh, S. P. and Verma, A. N. (foksh) Antwhess mech.1msm of cesstance (o stem borer. ( halo partellus (Swinhoc) in sorghum Insed S(1 $1 p)$ 9, 579 $5 x$ ?

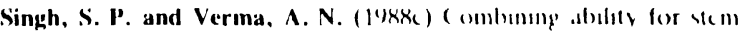

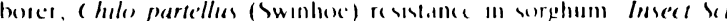
Appl 9, 61,5 , 06,8

Singh, S. P., Jotwani, M. (;. and Rana, B. S. (19)(1) 1)(welopment

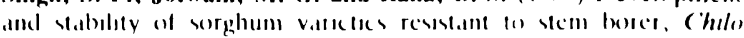
partellas (Swinhoc) Indan J I ntomol $42 \quad 173 \quad 181$

Singh, S. P., Jotwani, M. (;., Rana, B. S. and Rao, N. (;. P. (1978) stabilaty of host plant resstance to sorghum showe fly. Atherigona

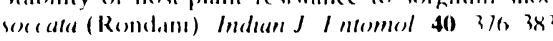

Singh, S. K., Vedmoorthy, (;., Ihobhi, V. V., Jotwani, M. (;., Young, W. K., Balan, J. S., Srivastava, K. P., Sandhu, (;. S. and

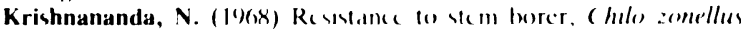

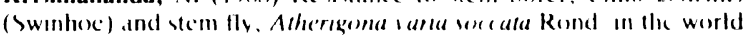

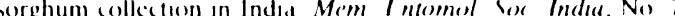

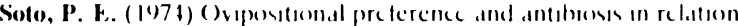

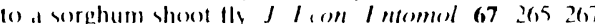

Srivastava, h. P. (1985) beremmg for stem bome tesistame In

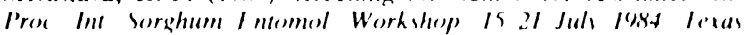

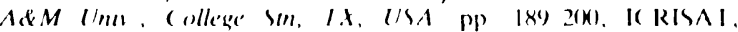
Patancheru, Andhra Pradesh. Indlat

Starks, K. J. and Mayo, Z. B., Jr (I985) Buology and control of gicen hug attaching sorghum In Pros lnt Sorghum I ntomol Workshop.

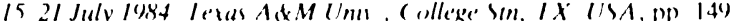
158, IC RISA I. Patancheru. Andhra Pradesh. India

Starks, K. J. and Schuster, D. J. (1976) (ircenbug effects of continuous culturing on resistant sorghum $I$ miron 1 momol 5 . 72()-723

Starks, K. J. and Weibel, D. E. (1981) Resstance in blexmless and sparse-blocom sorghum to greenbugs I moron L.momol 10,963965

Starks, K. J., Eberhart, S. A. and Doggett, H. (1970) Recovery from shoot fly attack in a sorghum diallel ( rop Set 10, 519522 
Starks, $\mathbf{J}$. Muniappan, $R$ and Fikenbar, $R$ D) (197') Intct action betucen plant resset ince ind pat witem ig umst the ercenbus on barks and sorghum inn $I$ neomol bas $1 \mathrm{~m}$ 65 0 (1)

Starks, h J, Wood, F A .Jr and Burton. R I (1974) Rolitlomhip

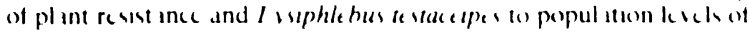

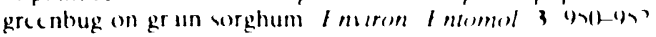

Swarup, I and (haugale, D) $>$ (1962) I prelimm in stud on

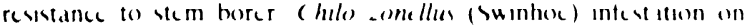
sorghum Sorghum iulgare Pers (urr la 31 lot $10 \mathrm{~d}$

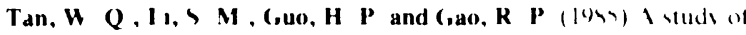

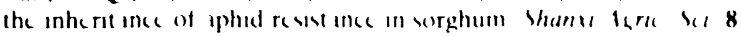
1214

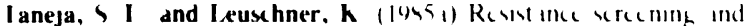
mech insems af resst ince in sothhum to shoset the In Pros Int sorshum I nomol Workshop is 21 Juh lost collese son II

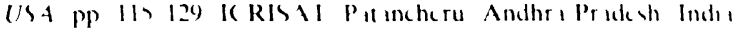

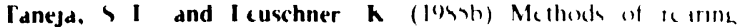

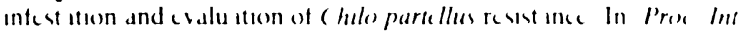
sorghum I ntomol Workshop) 1521 Juh lost collese sto 11

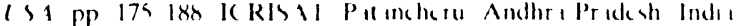

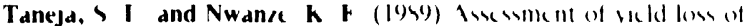

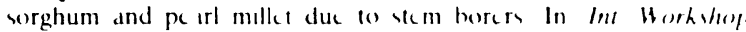

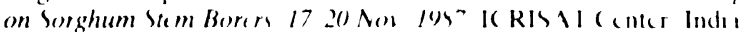
pp) 9510.4 IC RISAI Pancheru Andhra Pridesh Indis

Taneja, S I and Woodhead, S (1949) Mech tmoms of stem boler resst ince in sorghum in Int Workshop) on torshem stem Bomers 1720 No1 1947 IC RISA I ( onter Indis pP 13/ 1 14 I( RIS II Pil incheru Andh, , Pridesh Ind, ।

Teetes, (, I (1979) (),

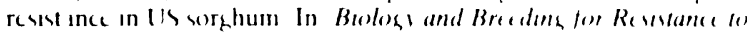

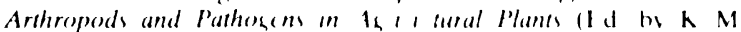

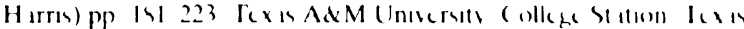

Teetes, (, I $(1980)$ Biccding sorghums resist int to insects In

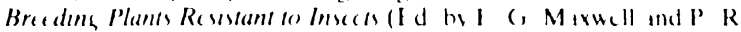
lennongs) pp (57-t5) John Wiles and Som Neu York

Teetes, (, I (1985) Inscet ressetant sorghums in pest m in igement Inseat sat ippl 6 4t3-45I

rectes, (, I , Becerra, M I and Peterson (, C (19xh) borshum madge (1)iptei ( coldomvisd a ) $m$ in ife ment with resst int sotgl um

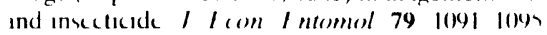

Teetes, (, I , Johnson, I W and kosenow, D I (1975) R(sponse of improved cesstant sorghum hibrids to natural and irtifical

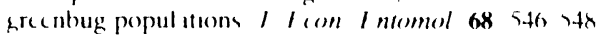

Teetes, (, I , schaefer, ( A and Johnson, I W (1974) Resest ince

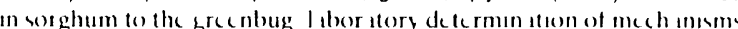
of resstince $/ 1$ and $/$ mtomol $67393 \quad 396$

leetes, (, I , Reddy, K V S, I cuschner, $h$ and House I $R$ (1983) Sorghum Insal Identification Ilandbosh Info Bull I) IC RISAI Pitancheru Andhri Pridesh Indi

Unnithan, (, I and Reddr, $K V$ S (1985) Owposition and infestation of the sorghum shoot fly Athe regona soecata $\mathrm{Ro}$ id ins on coitan sorghum cultivars in relition to their relitive resistiance and susceptibility Inset sel 1 ppl o $409-41$ )

Waquil, J M. Teetes, (, I and Peterson, (, ( (1985) Adult sorghum midge (I)ipter (ccidomvide) nomprefirence for 1 rcsistant sorghum hybrid $J$ Fon Fntomol 79 455-458

Waquil, I M, Teetes, (, I and Peterson, (, C (1986a) Sorghum midge (I)ıptcra (coldomyidac) adult oviposition behiwour on rcsistant and susceptible sorghum hybrids $J$ I con I ntomol 79 $53(1)-532$

Waquil, J M, Tcetes, (, I and Peterson, (, C (1986b) (om parison of $1 \mathrm{~mm}$ iture sorghum midge (Dipter (codomyidx)

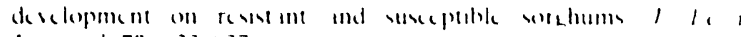
I nfelmol 79 433 437

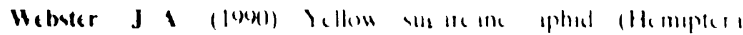

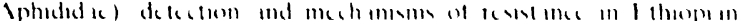

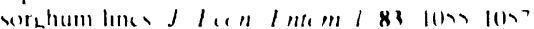

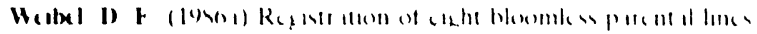

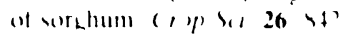

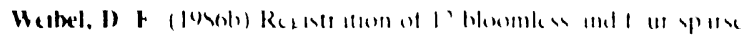

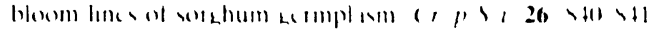

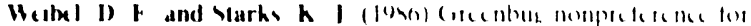

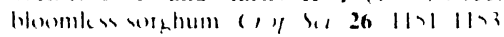

Widstrom V $W$ Wisman B $R$ and M/c Millian W $W(1 \%$ t)

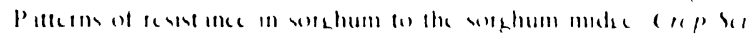
24701703

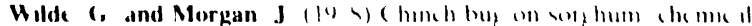

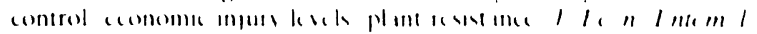
71 (1) पा1

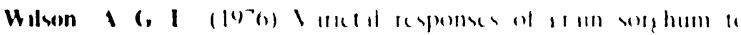

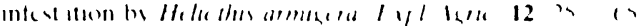

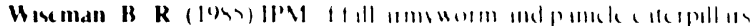

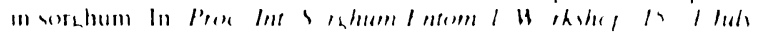

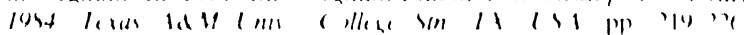

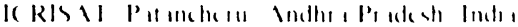

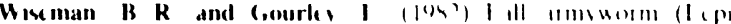

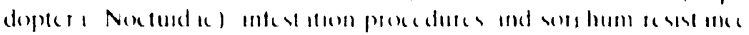

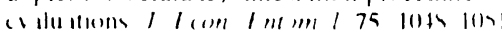

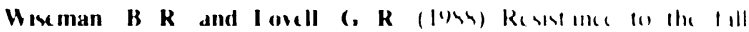

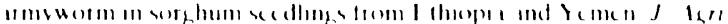
Intomol $5 \quad 17 \quad 0$

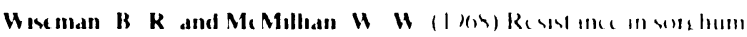

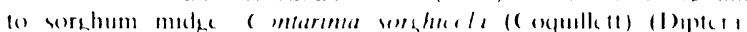

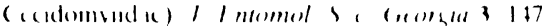

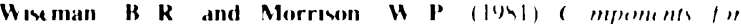

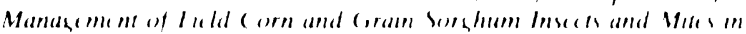

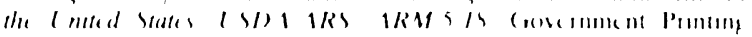

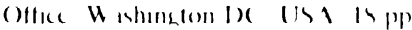

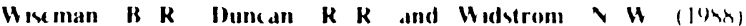

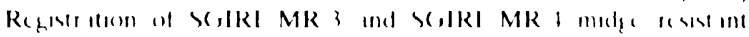

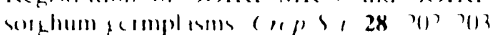

Wiseman B $\mathrm{K}$ MeMillan W $\mathrm{W}$ and Widstrom v W (1973)

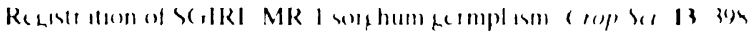

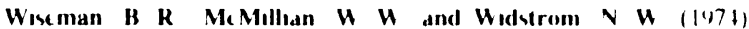

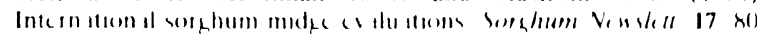
Wiseman, $B$ McMilian $W \quad W$ and Widstrom $\mathbf{N}(1975)$

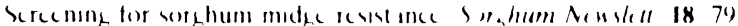
sil

Wiseman B $R$ Pitre H A courles, I and fales S I (19ht)

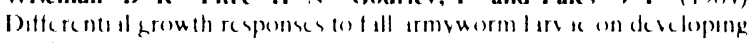
sorghum seck incorporiled inter a merade dee $1 / 1$ nesmolesest 67 $357 \quad 367$

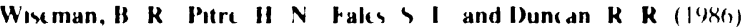

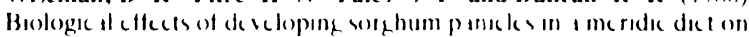
fill irmvworm (I cpedopter Nocfuid ce) de clopment $J$ I om I ntomol $79 \quad 1637 \quad$ 16.41

Woxdhead, S and I aneja, S I (1987) Ihe importince of the beh iviour of voung. lisve in sorphum resset ence tol ( hilo partellas I meomolosia (x) appl 454754

Recorved 20 september 1991

Revised 31 July 1992

Accuptcd 3 August 1992 